\title{
Nitrogen cycling in coastal sediment microbial communities with seasonally variable benthic nutrient fluxes
}

\author{
Alexis J. Marshall ${ }^{1,2,5, *}$, Andrew Longmore ${ }^{3}$, Lori Phillips ${ }^{2,6}$, Caixian Tang ${ }^{1}$, \\ Helen L. Hayden ${ }^{2}$, Karla B. Heidelberg ${ }^{4}$, Pauline Mele ${ }^{1,2}$ \\ ${ }^{1}$ La Trobe University, AgriBio Centre for AgriBiosciences, Melbourne, VIC 3086, Australia \\ ${ }^{2}$ Agriculture Victoria, Department of Jobs, Precincts and Regions, AgriBio, Centre for AgriBiosciences, Melbourne, \\ VIC 3086, Australia \\ ${ }^{3}$ Centre for Aquatic Pollution Identification and Management, Melbourne University, Parkville, VIC 3010, Australia \\ ${ }^{4}$ The University of Southern California, Department of Biology, Los Angeles, CA 90089, USA
}

${ }^{5}$ Present address: University of Waikato, Hillcrest, Hamilton 3216, New Zealand

${ }^{6}$ Present address: Agriculture and Agri-Food Canada, Harrow Research and Development Centre, Harrow, ON N0R1G0, Canada

\begin{abstract}
Benthic microbial communities contribute to nitrogen $(\mathrm{N})$ cycling in coastal ecosystems through taxon-specific processes such as anammox, nitrification and $\mathrm{N}$-fixation and community attributed pathways such as denitrification. By measuring the total (DNA-based) and active (RNAbased) surface sediment microbial community composition and the abundance and activity profiles of key N-cycling genes in a semi-enclosed embayment - Port Phillip Bay (PPB), Australia — we show that although the total relative abundance of N-cycling taxa is comparatively lower close to estuary inputs (Hobsons Bay [HB]), the capacity for this community to perform diverse N-cycling processes is comparatively higher than in sediments isolated from inputs (Central PPB [CPPB]). In $\mathrm{HB}$, seasonal structuring of the sediment microbial community occurred between spring and summer, co-occurring with decreases in the activity profiles of anammox bacteria and organic carbon content. No changes were detected in the activity profiles of nitrifiers or the community-based pathway denitrification. Although no seasonal structuring of the sediment microbial community occurred in $\mathrm{CPPB}$, the activity profiles of key N-cycling genes displayed comparatively higher within-site variability. These results show that despite N-cycling taxa representing a smaller fraction of the total community composition in estuary impacted sediments (HB) these microbial communities consistently engage in N-cycling processes and that seasonal instability in the composition of this community is not reflective of changes in its capacity to cycle $\mathrm{N}$ through coupled nitrification-denitrification but potentially via changes within the anammox community.
\end{abstract}

KEY WORDS: 16S rDNA $\cdot$ Coastal sediment $\cdot$ Nitrogen cycling $\cdot$ Seasonal variability $\cdot$ Spatial microbial variation $\cdot$ Temporal microbial variation

\section{INTRODUCTION}

In coastal systems, the sediment habitat supports a diverse microbial community capable of the nitrogen (N)-loss pathways denitrification and anaerobic oxi-

\footnotetext{
${ }^{*}$ Corresponding author: alexis.marshall@waikato.ac.nz
}

dation of ammonium (anammox) (Seitzinger et al. 2006, Devol 2015). Yet, within this habitat, environmental factors, macrofaunal activity, and microbial community composition have all been identified as potential deterministic factors for whether N-retention

() The authors 2021. Open Access under Creative Commons by Attribution Licence. Use, distribution and reproduction are unrestricted. Authors and original publication must be credited. 
or N-loss is favoured by the sediment microbial community. For example, environmental features of estuary sediments such as low nitrate/nitrite $\left(\mathrm{NO}_{3}{ }^{-} /\right.$ $\mathrm{NO}_{2}{ }^{-}$) availability and higher iron and organic carbon concentrations have been shown to favour the retention of biologically available reactive nitrogen $\left(\mathrm{N}_{\mathrm{r}}\right)$ species, such as $\mathrm{NO}_{3}{ }^{-} / \mathrm{NO}_{2}{ }^{-}$and ammonium/ ammonia $\left(\mathrm{NH}_{4}{ }^{+} / \mathrm{NH}_{3}\right)$ by favouring microbial dissimilatory nitrate reduction to ammonium rather than denitrification (Robertson et al. 2016, Kessler et al. 2018). Sulphide has also been shown to promote $N_{r}$ retention by restricting denitrification, nitrification and anammox (An \& Gardner 2002, Carvajal-Arroyo et al. 2013), but at the same time conflicting evidence suggests that it can indirectly promote $\mathrm{N}_{\mathrm{r}}$ loss by selecting for dissimilatory nitrate reduction to ammonium coupled to anammox (Russ et al. 2014, Jones et al. 2017). Reworking of the sediment by resident macrofauna can oxygenate deeper sediments, promote solute exchange, and generate redox oscillations, supporting $\mathrm{N}_{\mathrm{r}}$ loss via coupled nitrificationdenitrification (Rysgaard et al. 1995, Bertics et al. 2010, Gilbert et al. 2016). Complicating these environmental relationships is the complex and highly modular nature (e.g. denitrification) of the microbial $\mathrm{N}$-cycle, with a consortium of taxa involved in critical interlinked microbial transformations that result in partial or complete nutrient cycling (Kuypers et al. 2018). The complexity of these interactions is further compounded in coastal habitats, as these ecosystems are transitional zones between terrestrial and marine environments, where strong spatiotemporal heterogeneity in physicochemical and environmental conditions occur. Within these coastal environments, microbial communities have been shown to respond to spatial gradients of salinity, pollution, depth, nutrients, $\mathrm{pH}$, bioturbation and dissolved oxygen, and temporal gradients of temperature and rainfall (Böer et al. 2009, Fortunato et al. 2012, 2013, Sun et al. 2013, Wang et al. 2015, Angly et al. 2016, Jeffries et al. 2016, Ren et al. 2019). With a myriad of factors suggested to interact and potentially alter the composition and function of coastal microbial communities, a greater understanding is required in relation to how these communities respond to variable environmental conditions and the potential impacts these changes have on the critical ecosystem functions that these communities play.

Port Phillip Bay (PPB) is an almost landlocked embayment which covers an area of $1167 \mathrm{~km}^{2}$ on the south-eastern coastline of Australia. In this system, primary productivity is dominated by phytoplankton (predominantly diatoms) (Magro et al. 1996), the growth of which is limited by the availability of $\mathrm{N}_{\mathrm{r}}$, with annual demand exceeding external supply 5- to 10-fold (Harris et al. 1996, Berelson et al. 1998). There are 2 primary external inputs of $\mathrm{N}_{\mathrm{r}}$ within this system, the Yarra River estuary and the Western treatment plant, where the city of Melbourne's waste water is processed. Yet, $\sim 63 \%$ of the bioavailable $\mathrm{N}_{\mathrm{r}}$ is recyled to the water column by the sediment (Harris et al. 1996, Berelson et al. 1998). Physical factors attributed to the high $\mathrm{N}_{\mathrm{r}}$ loss within PPB include the high benthic area to total volume ratio, the large proportion of muddy fine-grained sediments, a relatively low external carbon input, the slow exchange rate with the open ocean $(\sim 1 \mathrm{yr})$, high sediment-water mixing, and bioturbation (Harris et al. 1996, Berelson et al. 1998, 1999, Murray \& Parslow 1999, Holdgate et al. 2001). These processes generate an environment in which the entire water column of PPB is predicted to cycle through the surface sediments 1-2 times before the water is exchanged with the open ocean (Harris et al. 1996, Berelson et al. 1999). In combination, these factors create optimum conditions for benthic loss of $\mathrm{N}_{\mathrm{r}}$ from the ecosystem by presenting both oxidised and reduced forms of $\mathrm{N}_{\mathrm{r}}$ repeatedly to the sediment microbial community. The efficiency of the sediment microbial community to remove $\mathrm{N}_{\mathrm{r}}$ within this system has been characterised through benthic chambers which measure the exchange of $\mathrm{N}_{2}, \mathrm{NH}_{4}{ }^{+}, \mathrm{NO}_{3}{ }^{-}$and $\mathrm{NO}_{2}{ }^{-}$from the sediment to the water column. These fluxes, expressed as the proportion of $\mathrm{N}_{\mathrm{r}}$ released as $\mathrm{N}_{2}$, have been measured seasonally in this system for more than $20 \mathrm{yr}$ (Berelson et al. 1998, Heggie et al. 1999, Longmore \& Nicholson 2012) and were used to generate a denitrification efficiency metric. Average bay-wide denitrification efficiency estimates for PPB are globally comparatively high (>60\%) (Eyre \& Ferguson 2009), yet high rates of $\mathrm{N}_{\mathrm{r}}$ retention within the northern region of the bay generate inefficient denitrification efficiency estimates close to estuary inputs where carbon decomposition rates are high $(1250 \mu \mathrm{mol} \mathrm{CO}$ $\mathrm{m}^{-2} \mathrm{~h}^{-1}$ ) (Berelson et al. 1998). Decreases in the denitrification efficiency in these estuary-impacted regions occur from spring to summer and are hypothesised to be driven by changes in the deposition rate of phytoplankton-derived detritus that settle on the sediment surface. In this model, increased carbon deposition stimulates microbial respiration, which consumes and depletes oxygen at the sediment-water interface, uncoupling nitrification-denitrification processes leading to environmental conditions that favour $\mathrm{N}_{\mathrm{r}}$ retention (Harris et al. 1996, Longmore \& Nicholson 2012). 
Despite the microbial community being attributed a critical role in mitigating the risk of nutrient enrichment in PPB via coupled nitrification-denitrification, there is a lack of basic understanding of its community composition. There is also a limited understanding of whether abiotic factors cause community compositional changes and whether these changes threaten the coupled microbial metabolic functions that lead to complete $\mathrm{N}$-cycling and $\mathrm{N}_{\mathrm{r}}$ loss. Differences in seasonal inputs from adjacent estuaries can affect the composition of coastal water-column bacterioplankton communities (Fortunato et al. 2013, Angly et al. 2016), and it is possible that seasonally driven structural changes also occur in these sediments, potentially impacting the community's capacity to perform complete $\mathrm{N}$-cycling. In this study we characterised the total (DNA-based) and active (RNA-based) surface sediment microbial community of PPB in conjunction with measures of denitrification efficiency and abundances of key $\mathrm{N}$-cycling genes and transcripts at 2 locations that differ in proximity to the primary estuary in both spring and summer. We used these data to investigate if compositional and functional stability of the sediment surface microbial community and the community capacity to cycle $\mathrm{N}$ reflect our well-characterised understanding of site and seasonal variability in denitrification efficiency at these sites (Berelson et al. 1998, Heggie et al. 1999, Longmore \& Nicholson 2012). In this study, we tested the hypothesis that estuary-impacted seasonal variability in benthic flux denitrification efficiency would be reflected in seasonal variability in microbial community composition and N-cycling gene profiles.

\section{MATERIALS AND METHODS}

\subsection{Study area and sediment sample collection}

Two locations within PPB, Australia - Central PPB (CPPB) $\left(38^{\circ} 03.495^{\prime} \mathrm{S}, 144^{\circ} 52.242^{\prime} \mathrm{E}_{;} 24 \mathrm{~m}\right.$ depth; depicted by circles throughout this study) and Hobsons Bay (HB) $\left(37^{\circ} 52.065^{\prime} \mathrm{S}, 144^{\circ} 55.654^{\prime} \mathrm{E} ; 11 \mathrm{~m}\right.$ depth idepicted by triangles throughout this study) were identified as having discrete biochemical signatures for N-cycling processes (Berelson et al. 1998, Heggie et al. 1999, Marshall et al. 2018) (Table 1, Fig. 1). In conjunction with benthic chamber flux measurements, sediment samples were collected from $\mathrm{CPPB}$ and $\mathrm{HB}$ at 4 time points, covering 2 spring (November 2014 and November 2015) and 2 summer (March 2015 and February 2016) sampling events.

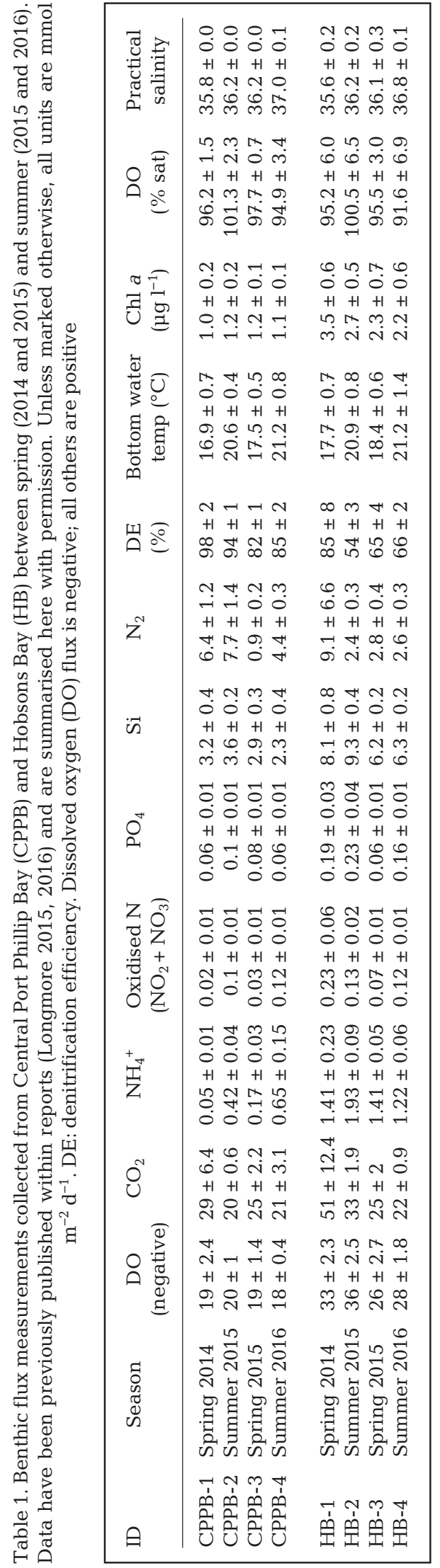




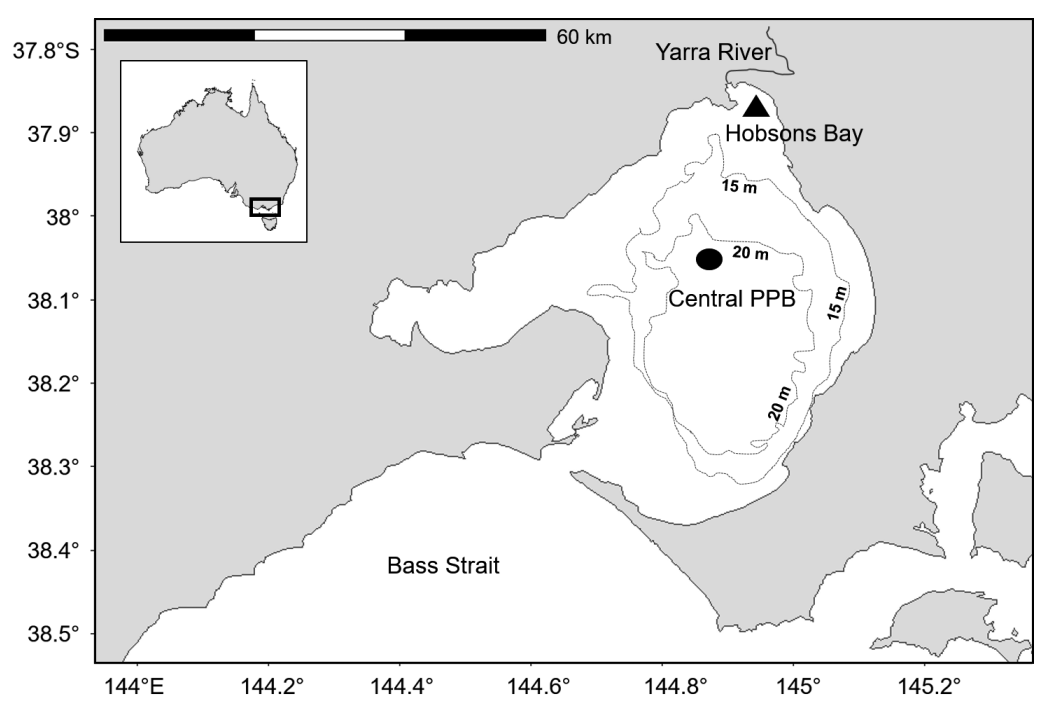

Fig. 1. Port Phillip Bay (PPB), Australia. Map depicts 15 and 20 m depth contours, the position of the Yarra River and the open ocean (Bass Strait), and the location of Central PPB (circle) and Hobsons Bay (triangle)

high density polyethylene (HDPE) containers, kept on ice and analysed within $6 \mathrm{~h}$. Samples for nutrient and alkalinity $\left(\mathrm{CO}_{2}\right)$ analysis were filtered through $0.4 \mu \mathrm{m}$ membrane filters into HDPE containers. Alkalinity samples were preserved with $\mathrm{HgCl}_{2}$ and refrigerated. Alkalinity was determined by Gran titration at $25^{\circ} \mathrm{C}$ (Dickson 1981). Nutrient samples were frozen and later analysed by standard segmented flow colorimetric methods (Parsons et al. 1984). Samples for dinitrogen $\left(\mathrm{N}_{2}\right)$ were stored in stoppered glass vials filled to overflowing, preserved with $\mathrm{HgCl}_{2}$ and kept under water at ambient water temperature. They were analysed by membrane inlet mass spectrometry (MIMS) at the Southern Cross University laboratories in Lismore, NSW, to a precision of $\sim 0.1 \%$, following the methods of Kana et al. (1998).

\subsection{Flux measurements}

At each time point within each site, denitrification efficiency was estimated from fluxes between the sediment and water column measured by pairs of automated or manual benthic chambers. For both the automated and manual method, 2 pairs of transparent cylindrical chambers (15 l volume; $0.062 \mathrm{~m}^{2}$ sediment area) each fitted with continuous dissolved oxygen (DO) and temperature sensors (2 min intervals; ZebraTech Dopto DO sensor) were deployed at each location. For the automated chambers a programmable erosion link (SubSeaSonics) closed the lid after 1-4 h (dependent on estimated settling time of resuspended sediments). Samples were collected in glass syringes $(120 \mathrm{ml})$ mounted in a deep-sea carousel (KC Instruments) from within the chambers at fixed intervals over the next $12-18 \mathrm{~h}$ (6 samples per chamber in all). For the manually operated chambers, divers placed the chambers on the seafloor with open sampling ports to allow complete flushing. After $30 \mathrm{~min}$, an initial sample was withdrawn by syringe from the chamber, and the sampling ports sealed. A final sample was taken prior to recovery of the chambers by divers after 16-20 h. Both automated and manual chambers were stirred constantly at a rate calculated to create a boundary layer of about $400 \mu \mathrm{m}$, similar to that created by bottom currents typically found in PPB $\left(2-5 \mathrm{~cm} \mathrm{~s}^{-1}\right)$. On recovery, the syringes were sub-sampled for dissolved $\mathrm{N}_{2}$, dissolved nutrients, $\mathrm{pH}$ and alkalinity. Samples for $\mathrm{pH}$ were collected in air-free
Fluxes were estimated by linear regression of nutrient concentration with time and extrapolated from the period of incubation to a daily rate. Chamber volume was estimated from video observation of a scale on the side of the chamber on deployment and recovery. Errors in flux estimates were calculated by combining errors from linear regression, chemical analysis and chamber volume.

\subsection{In situ water column measurements}

In situ data were collected at 30 min intervals with Seabird SBE 19plus CTD sensors, fitted with Wetlabs ECO-FLS chlorophyll $\alpha$ fluorescence sensors. Sensors were deployed on piles or buoys and serviced at bi-monthly intervals. Calibration samples for salinity and chlorophyll $\alpha$ were collected at the start, after $1 \mathrm{mo}$ and at the end of each deployment, to allow for correction for drift and fouling. Data are presented here as the mean $\pm \mathrm{SD}$ calculated for the month of sampling.

\subsection{Sediment and pore water chemistry}

At each time point, 5 undisturbed sediment cores were diver-collected at each site with a stainless-steel hand corer containing a $50 \mathrm{~mm}$ (diameter) $\times 500 \mathrm{~mm}$ (length) cellulose acetate butyrate plastic (CAB) internal liner (Wildco). Sediment pore water samples were 
collected from the sediment-water interface $(0-1 \mathrm{~cm}$ in summer 2015, spring 2015 and summer 2016) using standard Rhizon samplers (Rhizosphere Research) inserted into sealed pre-drilled holes in the CAB liners. The sediment was then pushed onto a modified sampling platform from the base of the CAB liner, and sterile $5 \mathrm{ml}$ syringes were used to collect surface sediment $(0-1 \mathrm{~cm})$. Each sediment sample was split into 3 sub-samples for RNA/DNA co-extraction and one larger sample for sediment chemical analysis. Samples were processed on location within 30 min of surfacing and were immediately snap frozen in liquid nitrogen, transferred to a cryoshipper and stored at $-80^{\circ} \mathrm{C}$ prior to extraction.

The sediment collected for chemical analysis was divided into 2 sub-samples. One sample was dried at $45^{\circ} \mathrm{C}$ to constant weight to calculate moisture content (water weight/wet weight). This sample was then ground to a fine powder (MM400, Retch), and $0.5 \mathrm{~g}$ was treated at $85^{\circ} \mathrm{C} 3$ times with $1 \mathrm{ml} \mathrm{5-6 \%} \mathrm{H}_{2} \mathrm{SO}_{3}$ (Merck kGaA, EMSURE) to determine total $\mathrm{N}$ and total organic carbon (LECO TruMac auto analyser; Skjemstad \& Baldock 2007) with in-house standards at Agriculture Victoria, Department of Jobs, Precincts and Regions.

The second sub-sample was centrifuged (3000 rpm, $1000 \times g$, for $5 \mathrm{~min}$ ), and its $\mathrm{pH}_{\mathrm{H} 2 \mathrm{O}}$ was measured directly from the overlying pore-water (Hanna Instruments). The sediment was resuspended prior to the addition of $2 \mathrm{M} \mathrm{KCl}$ to a final volume of $9 \mathrm{ml}$. Samples were mixed via inversion ( $1 \mathrm{~h}$ ) on a horizontal shaker and centrifuged at $3000 \mathrm{rpm}, 1000 \times g_{1}$ for $5 \mathrm{~min}$. The $\mathrm{KCl}$-extractable $\mathrm{NO}_{3}{ }^{-}+\mathrm{NO}_{2}{ }^{-}\left(\mathrm{NO}_{\mathrm{x}}-\mathrm{N}\right)$ and $\mathrm{NH}_{4}{ }^{+}-\mathrm{N}$ from wet sediment samples were analysed via segmented flow-injection analysis (Skalar SAN++) against a standard curve with the following detection limits of $0.02 \mathrm{mg} \mathrm{l}^{-1}$ for $\mathrm{NH}_{4}{ }^{+}-\mathrm{N}$ and $0.01 \mathrm{mg} \mathrm{l}^{-1}$ for $\mathrm{NO}_{\mathrm{x}}-\mathrm{N}$. The remaining wet sediment was dried at $45^{\circ} \mathrm{C}$ to constant weight, and the sediment dry weight and volume was calculated with a predicted rho of 1.5 (Greilach 1996). The concentrations of $\mathrm{NO}_{\mathrm{x}}-\mathrm{N}$ and $\mathrm{NH}_{4}{ }^{+}-\mathrm{N}$ were converted to $\mathrm{mg} \mathrm{kg}^{-1}$ by factoring in the total volume of pore-water and $2 \mathrm{M} \mathrm{KCl}$, and dry sediment weight. Rhizon-collected pore-water was analysed for $\mathrm{NO}_{2}{ }^{-}-\mathrm{N}, \mathrm{NO}_{3}{ }^{-}-\mathrm{N}$ and $\mathrm{NH}_{4}{ }^{+}-\mathrm{N}$ with the segmented flow analyser.

\subsection{Sediment nucleic acid extraction}

Nucleic acids (RNA and DNA) were co-extracted from 3-6 $\mathrm{g}$ wet sediment using the RNeasy Power Soil Total RNA extraction kit with DNA elution ac- cessory kit (QIAGEN). Extract quality (gel electrophoresis) and quantity (NanoDrop 2000, ThermoFisher Scientific) were confirmed. Eluted RNA was treated with the Turbo DNA-free kit (Ambion Life Technologies), and successful removal of residual DNA was confirmed by quantitative PCR (qPCR) amplification of $10 \mathrm{ng}$ of DNase treated RNA with 16S rRNA primers 515f/806r (Caporaso et al. 2012). At this point, 3 of the 5 sampled cores were selected for RNA and DNA sequence analysis based on high quality extraction metrics. Superscript IV (Invitrogen) with random hexamers was used to synthesize cDNA (1.5 ng $\mathrm{\mu l}^{-1}$ cDNA final concentration) along with no template controls (NTC). For additional quality control RNA and DNA extraction blanks were carried through all processing steps.

\subsection{Library preparation and 16S rRNA sequencing}

The V4 hypervariable region of the 16S rRNA gene was amplified using 515F-Y/926R primers (Parada et al. 2016) modified for 2-step PCR amplification following the method of Kozich et al. (2013). Each sample was PCR-amplified in triplicate reactions containing either $12.5 \mathrm{ng}$ total cDNA, $12.5 \mathrm{ng}$ total DNA or $10 \mu \mathrm{l}$ of protocol extraction blanks. Replicates were pooled and a modified Illumina 16S rRNA amplicon sequencing library protocol was followed (Illumina 2013). The protocol was modified at the index PCR step where $5 \mu$ l of diluted 1:10 bead cleaned PCR product and $5 \mu$ of $5 \times$ diluted Nextera XT Index Primer 1 and Index Primer 2 was added to the indexing reaction. The dilution was required as trial sequencing runs produced reads with below expected Q-scores. The final product size for Illumina MiSeq 3000 sequencing was confirmed (High Sensitivity D1000 Screen Tape, TapeStation, Agilent Technologies), library concentration determined (Qubit flurorometry, ThermoFisher Scientific), and $5 \mu \mathrm{l}$ of $45 \mathrm{nM}$ library from each sample were pooled. The final pooled library was diluted to $7 \mathrm{pM}$ and spiked with $20 \%$ vol 20 pM PhiX. Pooled libraries were sequenced on an Illumina MiSeq using Illumina MiSeq V3 $2 \times 300$ bp chemistry in-house at the Centre for AgriBiosciences, Victoria, Australia.

\subsection{N-cycle functional gene and transcript quantification}

This study targeted the conserved functional genes encoding ammonia monooxygenase (bacterial $\beta$-amoA, 
Rotthauwe et al. 1997; and archaeal amoA, Wuchter et al. 2006, Marshall et al. 2018), nitrite reductase (nirS, nirK, Braker et al. 1998; and archaeal nirK-a, Lund et al. 2012), nitrogenase (nifH, Rösch et al. 2002) and 16S rRNA phylogenetic markers specific for bacteria involved in the anaerobic oxidation of ammonia (16S rRNA anammox, Li et al. 2010) (Table S1 in the Supplement at www.int-res.com/articles/suppl/a086 p001_supp.pdf). Plasmid standards for qPCR were generated for each gene of interest from PPB sediment environmental DNA in $50 \mu \mathrm{l}$ PCR reactions containing $25 \mu \mathrm{l}$ GoTaq Green Master Mix (Promega) and $20 \mathrm{ng}$ total sediment DNA. Products of the expected size were confirmed (1.2\% TAE agarose gel, run at $80 \mathrm{~V}$ for $1 \mathrm{~h}$ ), cleaned (QIAquick PCR purification kit, Qiagen), pooled and cloned using a TOPO TA Cloning kit, dual promoter with One Shot TOP10 chemically competent Escherichia coli cells (Invitrogen) following the manufacturer's instructions. Positive colonies were grown overnight at $37^{\circ} \mathrm{C}$, plasmid DNA was extracted using a QIAprep Spin Miniprep kit (Qiagen), and the expected insert was verified by re-amplification with plasmid DNA. Plasmids containing single amplified products of the expected size were sequenced with Big Dye v3.1 kit on an ABI 3730xl DNA analyser (Applied Biosystems). Sequences were aligned at the primer-binding site and manually checked with Sequencher 5.1 (Gene Codes Corporation) and compared to the GenBank database (Altschul et al. 1990). Sequences have been deposited in GenBank (MH190789-MH190795) (Table S1).

The qPCR conditions for each gene were optimised using either BIORAD SSO Advance Universal SYBR Green Supermix or Bioline SeniFAST SYBR NOROX mix. Final primer concentrations of $0.5 \mu \mathrm{M}$ were optimized in $10 \mu \mathrm{l}$ reaction volumes and quantified in 384-well BIORAD qPCR plate format. Efficiencies ranged from $85 \%$ (bacterial nirK) to $101 \%$ (archaeal nirK). For the $16 \mathrm{~S}$ rRNA anammox qPCR reaction $0.2 \mu \mathrm{g} \mathrm{ll}^{-1}$ UltraPure Bovine Serum Albumin (Ambion) was added to optimize reaction efficiency. The final reaction conditions can be found in Table S1. Technical reproducibility for all qPCR reactions (NORT, RT-qPCR, qPCR) was assessed for each sample in duplicate (archaeal amo $A, \mathrm{R}^{2}>0.89$; bacterial $\beta$ amoA, $\mathrm{R}^{2}>0.96 ; \operatorname{nirs}, \mathrm{R}^{2}>0.93 ; \operatorname{nirK}, \mathrm{R}^{2}>0.68$; archaeal nirK-a, $\mathrm{R}^{2}>0.97$; nifH, $\mathrm{R}^{2}>0.75$; and $16 \mathrm{~S}$ rRNA anammox, $\left.R^{2}>0.96\right)$. Gene copy numbers per ng of DNA or cDNA were calculated from the average quantification cycle $\left(\mathrm{C}_{\mathrm{q}}\right)$ of 2 replicates against a standard curve (5-fold dilution with a linear range $8.00 \times 10^{-2}$ to $1.02 \times 10^{-6}$ ), taking into account the length of the plasmid standard, Avogadro's number and the average weight of a single DNA base pair of 650 Da. Three copies $\mathrm{ng}^{-1}$ were accepted as the detection limit (Bustin et al. 2009). Copy numbers were converted into per gram dry weight (DW) sediment (DNA g ${ }^{-1}$ DW and cDNA g ${ }^{-1}$ DW) using the pre-defined moisture content $(\mathrm{MC}=$ water weight/wet weight) estimate $[\mathrm{DW}=$ wet weight/ $(\mathrm{MC}+1)]$ for each sample. Untransformed copy numbers were not normally distributed and are reported here as the $\log _{10}$ copies $\mathrm{g}^{-1} \mathrm{DW}$ to meet the assumptions of ANOVA.

\subsection{Sequence data analysis}

Samples were de-multiplexed, and quality statistics were inspected using FastQC v0.10.1 (Andrews 2012). Raw data can be found on the NCBI Short Read Archive (PRJNA594213). Sequence reads without full length forward or reverse primers were discarded (10\% error allowance, Cutadapt v1.9; Martin 2011). A sliding window of $50 \mathrm{bp}, \mathrm{Q}$-score average 33 with minimum read length of $245 \mathrm{bp}$ (read 1) and 185 bp (read 2) were applied (Trimmomatic v0.32; Bolger et al. 2014). All read lengths below set minimums and quality filter parameters were discarded. Trimmed reads were processed following the recommended DADA2 pipeline (v1.14.1) (Callahan et al. 2016) to call amplicon sequence variants (ASV). The table of quality-controlled read counts was filtered using a minimum ASV abundance cut off threshold of $0.005 \%$ as recommended when a mock community is not incorporated (Bokulich et al. 2013). Taxonomy prediction was called against the SILVA database v138 (Quast et al. 2013) with DECIPHER 2.14.0 (Wright 2016). The unweighted pair group method with arithmetic mean (UPGMA) was used to construct the phylogenetic tree from the list of ASVs remaining after the threshold abundance cut off was applied in MUSCLE (Edgar 2004a,b).

\subsection{Statistics}

The following analyses were carried out in the $\mathrm{R}$ statistical package (v 3.5.1) with R-studio v1.1.463 (R Core Team 2014, RStudio Team 2016). Alpha-diversity values were calculated using Faith's standardized effect size of phylogenetic diversity (PD) (Faith 1992) in the R package Picante (v 1.7) (Kembel et al. 2010) applied to the $0.005 \%$ culled and unrarefied data matrix (Fig. S1); significant differences were tested with pairwise Wilcoxon rank sum test with the 
default Holm correction. Beta diversity was assessed using the phylogenetic isometric log-ratio (PhILR v 1.8.1) (Silverman et al. 2017) applied to an unrarefied data matrix with significant differences determined with ADONIS in the Vegan package (v 2.5-4) (Dixon 2003). To determine which ASVs were compositionally different between CPPB and HB and between spring and summer within each site, the analysis of the composition of microbiomes (ANCOM v 1.1-3) (Mandal et al. 2015) and EdgeR (Robinson et al. 2010) were applied to unrarefied data. The 2 factors in the analysis of variance (ANOVA) were site (CPPB and HB) and season (spring [2014/2015] and summer [2015/2016]). The interaction between site and season was also tested. Within each site the 2 factors tested were season and individual sampling date (November 2014, March 2015, November 2015, February 2016).

\section{RESULTS}

\subsection{Denitrification efficiency and benthic flux measurements}

Despite the proximity of HB to a freshwater source (Yarra River, Fig. 1), salinity and temperature were similar at both CPPB and HB. Chlorophyll a concentration was higher on all occasions and more variable at HB than at CPPB (2.2-3.5 cf. 1.0-1.2 $\left.\mu \mathrm{g}^{-1}\right)$. DO in bottom water was close to saturation (92-101\%) on all occasions at both sites. DO flux was higher on all occasions and more variable at HB than CPPB (26-36 cf. 18-20 mmol $\mathrm{O}_{2} \mathrm{~m}^{-2} \mathrm{~d}^{-1}$ ). $\mathrm{CO}_{2}$ flux was higher at HB than CPPB in spring 2014 and summer 2015, but similar at both sites in spring 2015 and summer 2016. The total dissolved $\mathrm{N}$ flux $\left(\mathrm{N}_{2}+\mathrm{NH}_{4}+\mathrm{NO}_{\mathrm{x}}\right)$ was dominated by $\mathrm{N}_{2}$ flux, with no clear spatial or seasonal pattern. $\mathrm{NH}_{4}$ flux was higher at HB than CPPB on all occasions. $\mathrm{NO}_{\mathrm{x}}$ flux was lower than $\mathrm{NH}_{4}$ flux and was similar at both sites. Phosphate flux was higher at HB than CPPB except in spring 2015, when fluxes were similar at both sites. Silicate flux was higher and more variable at HB than CPPB (6.2-9.3 cf. 2.3-3.6 mmol Si m $\mathrm{m}^{-2} \mathrm{~d}^{-1}$ ). The denitrification efficiency was lower at HB than CPPB on all occasions (54-85 cf. 82-98\%). The denitrification efficiency in HB decreased from $85 \pm 8$ in spring 2014 to $54 \pm 3$ in summer 2015, but not between spring 2015 (65 \pm 4 ) and summer 2016 (66 \pm 2 ). Within CPPB, the denitrification efficiency was similar between spring and the following summer (Table 1) (data are summarised with permission from Longmore 2015, 2016).

\subsection{Physicochemical parameters of the surface sediment}

Surface sediment chemistry differed between CPPB and HB, and seasonally within-site (Fig. 2). Sediment total $N\left(F_{[1,20]}=6.6 \times 10^{30}, \mathrm{p}<0.001\right)$ and total organic carbon (TOC) $\left(F_{[1,20]}=651, \mathrm{p}<0.001\right)$ were significantly higher at CPPB than HB. A significant interaction was identified for TOC between site and season $\left(F_{[1,20]}=17, \mathrm{p}<0.001\right)$, and when investigated within each site seasonal decreases in TOC from the spring and the following summer were only identified at $\operatorname{HB}\left(F_{[1,8]}=25, \mathrm{p}<0.001\right)$. The TOC:N ratio was significantly lower in CPPB than $\mathrm{HB}$ sediments $\left(F_{[1,20]}=\right.$ $15, \mathrm{p}<0.01)$, with seasonal decreases from spring to summer identified at both sites $\left(F_{[1,20]}=13, \mathrm{p}<0.01\right)$. Sediment $\mathrm{NH}_{4}{ }^{+}-\mathrm{N}$ concentration tended to be lower at CPPB than HB, with a seasonal increase in CPPB identified from spring to summer, though not significant at $\mathrm{p}=0.05$. No site or seasonal differences were observed in concentrations of $\mathrm{NO}_{2}^{-}-\mathrm{N}+\mathrm{NO}_{3}{ }^{-}-\mathrm{N}$ in the sediment yet the concentrations decreased from spring to the following summer in $\mathrm{HB}$, with less variability measured in HB sediments collected in summer than spring. Sediment moisture content was higher at CPPB than HB $\left(F_{[1,20]}=41, \mathrm{p}<0.001\right)$, with seasonal decreases at both sites between spring and the following summer $\left(F_{[1,20]}=9, \mathrm{p}<0.01\right)$. The $\mathrm{pH}$ of the sediment pore-water in CPPB was on average 0.3 units higher than in $\mathrm{HB}\left(F_{[1,13]}=40, \mathrm{p}<0.001\right)$, with no seasonal changes identified at either site. Though highly variable, the overall pore-water $\mathrm{NH}_{4}{ }^{+}-\mathrm{N}$ concentration was lower at CPPB than HB $\left(F_{[1,14]}=3.1\right.$, $\mathrm{p}=0.09$ ), with a non-significant increase from spring to summer in CPPB. No differences were identified in the concentration of pore water $\mathrm{NO}_{3}{ }^{-} \mathrm{N}$ or porewater $\mathrm{NO}_{2}{ }^{-}-\mathrm{N}$ concentrations.

\subsection{Amplicon quality control and alpha diversity}

ASVs with less than 169 cumulative reads across both DNA and RNA samples were removed when a $0.005 \%$ ASV abundance threshold was applied. After all quality filtering steps, a total of 2849636 merged reads were retained representing 3934 ASVs (retaining $85 \%$ of the generated ASV diversity and $79 \%$ of the original QC paired-end read counts after filtering). One sample (HB-4B DNA) contained <10000 reads after filtering. This sample was retained as it did not influence the data interpretation (Figs. S1 \& S2, Table S2). One sample (HB-1C) was identified as an outlier in both the RNA and DNA datasets. Data 

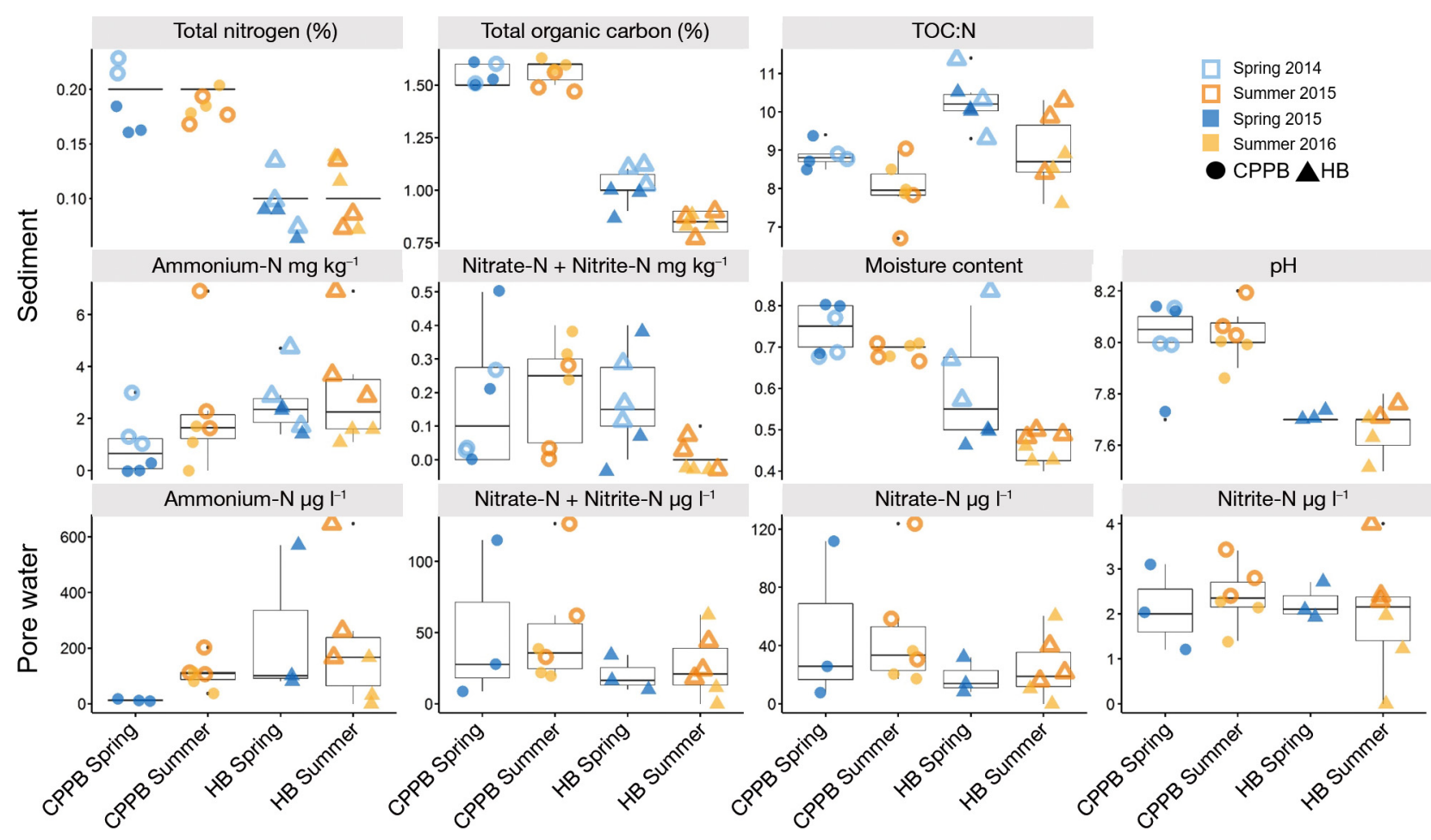

Fig. 2. Chemical characteristics of the surface sediment (top 2 rows) and sediment pore water (bottom row) sampled from Central Port Phillip Bay (CPPB, circles) and Hobsons Bay (HB, triangles) in spring 2014 and 2015 and summer 2015 and 2016.

TOC: total organic carbon

were analysed with this sample removed with no impact identified on the data interpretation (Fig. S2). The sequenced protocol blanks generated zero read counts after quality control (QC) filtering (Table S2). This QC approach combined with taxonomy assignment with release v138 of the SILVA database identified 3307 bacterial, 27 archaeal and 600 unclassified ASVs at the level of domain. Of these unclassifiable ASVs the average read count across samples for the combined DNA and RNA datasets was 413, with a range from 169 to 6972 and median 282 reads. For these 600 unclassifiable ASVs, taxonomy was assigned using Blast ${ }_{n}$ against the 16S ribosomal RNA (bacteria and archaea) database and nucleotide collection (nr/nt). Within the active (RNA) community the top 3 most abundant (0.1-0.2\%) and unclassified reads across sites aligned to uncultured Nitrospirales 16S rRNA (95-98\% identity) clones. Within the total (DNA) community the top 3 most abundant (0.1$0.2 \%$ ) and unclassified reads aligned to uncultured Nitrospirales, Deferribacteres and Actinobacterium 16S rRNA clones, respectively (95-99\% identity). Many of the other unclassified reads were identified as diatom plastids or unassigned environmental sequences. The relative abundance of the unclassified Nitrospirales 16S rRNA sequences was higher in
CPPB sediments than HB sediments. All analyses were conducted with unclassified reads either removed (3334 ASVs containing 2598881 reads; $91 \%$ of the $\mathrm{QC}$ processed read count) or retained. No measurable impact on the interpretation within the context of this study was identified. Data are presented with reads classified by Decipher against the v138 SILVA database at the domain level only. At the level of order, 68 ASVs were identified as Chloroplast and were removed from the main analysis.

Across all samples and nucleic acid types, species richness (SR) ranged from 1317 to 2784 (excluding HB-4B DNA [species richness, SR 493]) and the standardized effect size PD ranged from -21.2 to -11.9 (excluding HB-4B DNA [PD -15.5]) (Table S2). Comparatively, the species richness and $\mathrm{PD}$ of the active (RNA) microbial community in the sediment was lower at CPPB (SR $2043 \pm 346$; PD $-14.1 \pm 1.6$ ) than HB (SR $2481 \pm 357$; PD $-19.3 \pm 1.4)(\mathrm{n}=24, \mathrm{p}<0.05)$, but no difference was identified in the total (DNA) community. No significant differences were identified in species richness or PD between spring and summer or within each location $\times$ season interactions for either the active or total microbial community.

The dominant phyla identified in PPB sediments were Proteobacteria (28-30\%), followed by Desulfo- 
bacterota (14-15\%) and Bacteroidota (10-14\%). At the level of class Gammaproteobacteria (24-25\%), Desulfobacteria (6-11\%), Bacteroidia (10-13\%) and unclassified taxa (19-20\%) were dominant sequences across samples.

In the sediments $12-22 \%$ of the total relative abundance was constrained within the 20 most abundant ASVs (Fig. S3). Within the active (RNA) community, the 20 most abundant ASVs were associated with Gammaproteobacteria orders Nitrosococcales (1 ASV Nitrosococcaceae AqS1) and BD7-8 (3 ASVs), Desulfobacterota (2 ASVs unclassified) order Desulfobacterales (6 ASVs family Desulfosarcinaceae Sva0081), Desulfurmonadia order Sva1033 (1 ASV), Desulfobulbia order Desulfobulbales (1 ASV) and the Nitrososphaeria order Nitrosopumilales (3 ASVs family Nitrosopumilaceae), the phylum NB1-j (1 ASV) and 2 bacterial ASVs unclassified at the level of phylum (Fig. S3A). Within the total (DNA) community, the 20 most abundant ASVs were associated with Bacteroidia order Flavobacteriales (2 ASVs genus Lutimonas), Gammaproteobacteria order Steroidobacterales (1 ASV family Woeseia), Nitrosococcales (1 ASV genus AqS1), BD7-8 (2 ASVs) and unclassified Gammaproteobacteria (2 ASVs), Desulfobacteria (2 ASVs unclassified) order Desulfobacterales (4 ASVs family Desulfosarcinaceae Sva0081), Desulfobulbia order Desulfobulbales (2 ASVs), Desulfuromonadia order Sva1033 (1 ASV) and Nitrososphaeria order Nitrosopumilales (1 ASV family Nitrosopumilaceae) with 2 ASVs unclassified at the level of phylum (Fig. S3B).

Of the easily classifiable $\mathrm{N}$-cyclers within these sediments, the dominant family were Nitrosopumilaceae (RNA 3.5\%, DNA 2\%) followed by Nitrosococcaceae (RNA $2.5 \%$, DNA $0.8 \%$ ), Nitrospiraceae (RNA $0.7 \%$, DNA $0.6 \%$ ), Nitrospinaceae (RNA $0.6 \%$, DNA $0.3 \%$ ), Nitrosomonadaceae (RNA 0.6\%, DNA $0.3 \%$ ) and Nitrincolaceae (RNA $0.05 \%$, DNA $0.007 \%$ ) (Fig. S4).

\subsection{Spatial variability of the surface sediment microbial community}

Surface sediment microbial communities clustered strongly by site with PCoA1 explaining $50-51 \%$ of the variance (Fig. 3A [RNA] and Fig. 3B [DNA]; PhILR, $r>0.93, p<0.001$ ).

Between HB and CPPB, ANCOM identified 774 (RNA) and 762 (DNA) ASVs with significantly different relative abundances (ANCOM, $\mathrm{p}<0.05)$, whereas EdgeR identified 1678 (RNA) and 1443 (DNA) site-
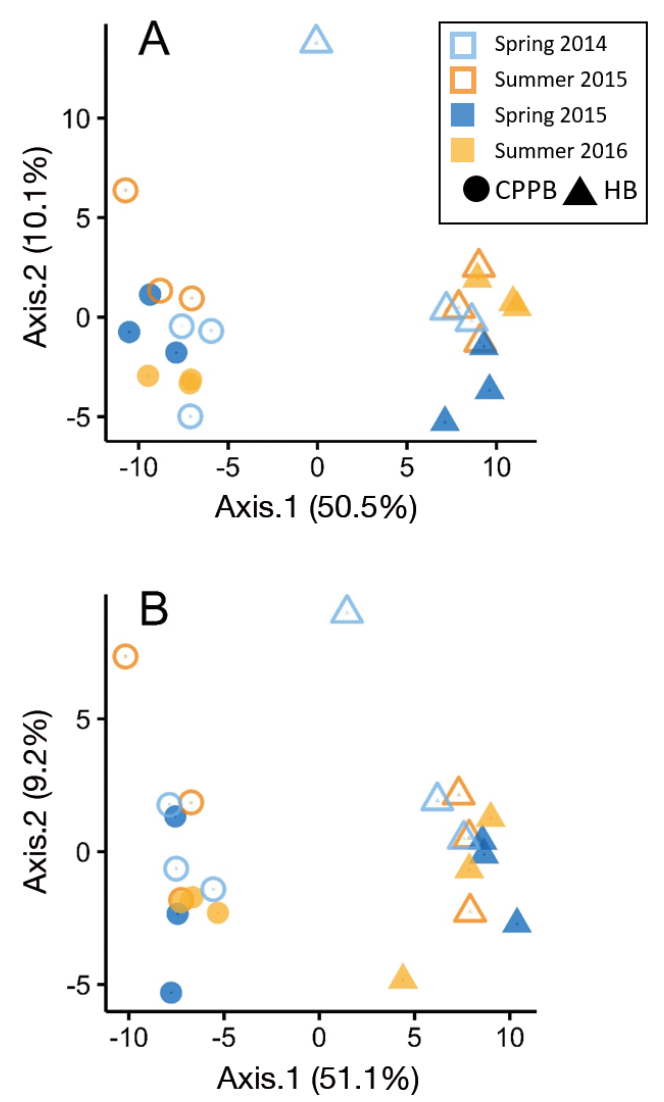

Fig. 3. Composition of the (A) active and (B) total surface sediment microbial community between Central Port Phillip Bay $\left(\mathrm{CPPB}_{;} \mathrm{n}=12\right.$, circles) and Hobsons Bay $(\mathrm{HB} ; \mathrm{n}=12$, triangles) in spring 2014 and 2015 and summer 2015 and 2016

based differences (EdgeR, $\mathrm{p}<0.001)$. Those ASVs that were identified by both techniques and classified past the phylum level (RNA 527 and DNA 657) are visualised at the level of order in Fig. S5 (RNA) and Fig. S6 (DNA). The following summary focuses on the site-based differences identified with ANCOM $(p<0.05)$. Many of the taxonomic differences in relative abundance between CPPB and HB were associated with dominant sediment classes, i.e. Gammaproteobacteria (RNA 223, DNA 231), Bacteroidia (RNA 65, DNA 95), Alphaproteobacteria (RNA 30, DNA 37), Desulfobacteria (RNA 35, DNA 21), Desulfobulbia (RNA 35, DNA 13) and Planctomycetes (RNA 18, DNA 22). To identify broad taxonomic differences between $\mathrm{CPPB}$ and $\mathrm{HB}$, these significant ASVs were subset from the total dataset, merged at the order level and the orders with a combined total relative abundance greater than $2 \%$ were used to display the largest site-based differences (Fig. 4A RNA, Fig. 4B DNA). At the order level, CPPB sediments could be differentiated from HB sediments by 
A

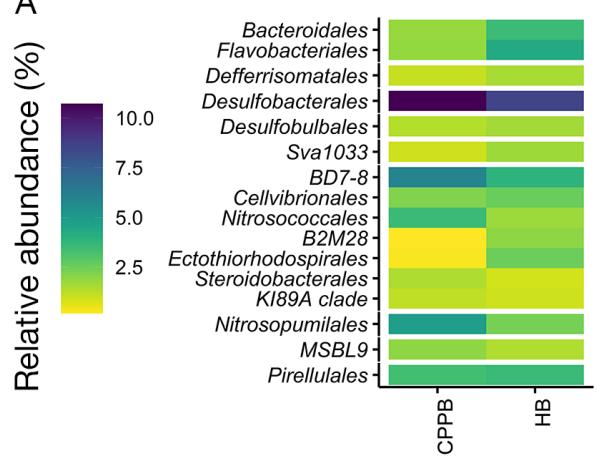

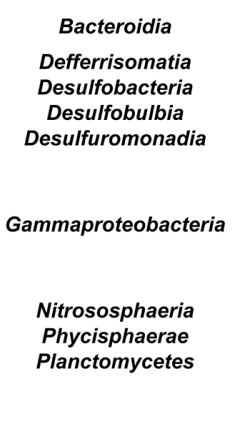

B

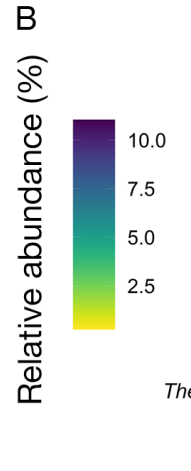

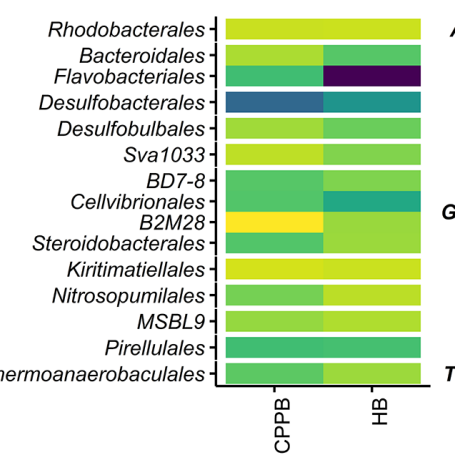

Alphaproteobacteria

Bacteroidia

Desulfobacteria

Desulfobulbia

Desulfuromonadia

Gammaproteobacteria

Kiritimatiellae Nitrososphaeria Phycisphaerae Planctomycetes Thermoanaerobaculia

Fig. 4. Relative abundances of select microbial taxa identified with site-based differences by analysis of the composition of microbiomes (ANCOM) $(\mathrm{p}<0.05)$ between Central Port Phillip Bay (CPPB) and Hobsons Bay (HB) within the (A) active and (B) total microbial community composition. Relative abundances (\% of total) of the identified taxa were grouped at the taxonomic level of order; orders with a relative abundance $2 \%$ displayed to depict the main differences between CPPB and HB sediment communities

a higher relative abundance of Nitrosopumilales, Desulfobacterales, Nitrosococcales (RNA only), BD7-8, Steroidobacterales, MSBL9 and Thermoanaerobaculales (DNA only), and a lower relative abundance of Flavobacteriales, Bacteroidales, Desulfobulbales, Defferrisomatales (RNA only), Sva1033, Ectothiorhodospirales (RNA only), B2M28 and Cellvibrionales. Many of these site-based differences were consistent between the total and active communities (Fig. 4).

The total relative abundance of all ASVs associated with known $\mathrm{N}$-cycling taxa were higher in CPPB than HB (Fig. S4). The largest site-based differences (ANCOM, p < 0.05) were in the relative abundances of Nitrosococcaceae (RNA 15 ASVs, DNA 15 ASVs, 8 ASVs were shared) and Nitrosopumilaceae (RNA 6
ASVs, DNA 4 ASVs, 3 ASVs were shared) (Fig. 5). The majority of the differences could be attributed to the relative abundance of a single Nitrosoccaceae AqS1 (ASV_13 RNA/DNA) and a single Nitrosopumilaceae (ASV_6 RNA/DNA) ASV (Fig. S7). Both of these ASVs were also identified within the top 20 dominant ASVs within these sediments (Fig. S3). Members of the Nitrosomonadaceae and Nitrospinaceae were also comparatively higher within the CPPB community (Fig. 5).

The presence and activity of functional markers for the sediment nitrifying, anammox, denitrifying and diazotroph microbial communities varied between $\mathrm{CPPB}$ and $\mathrm{HB}$, with a higher abundance of all profiles measured in HB sediments (Fig. 6). The CPPB
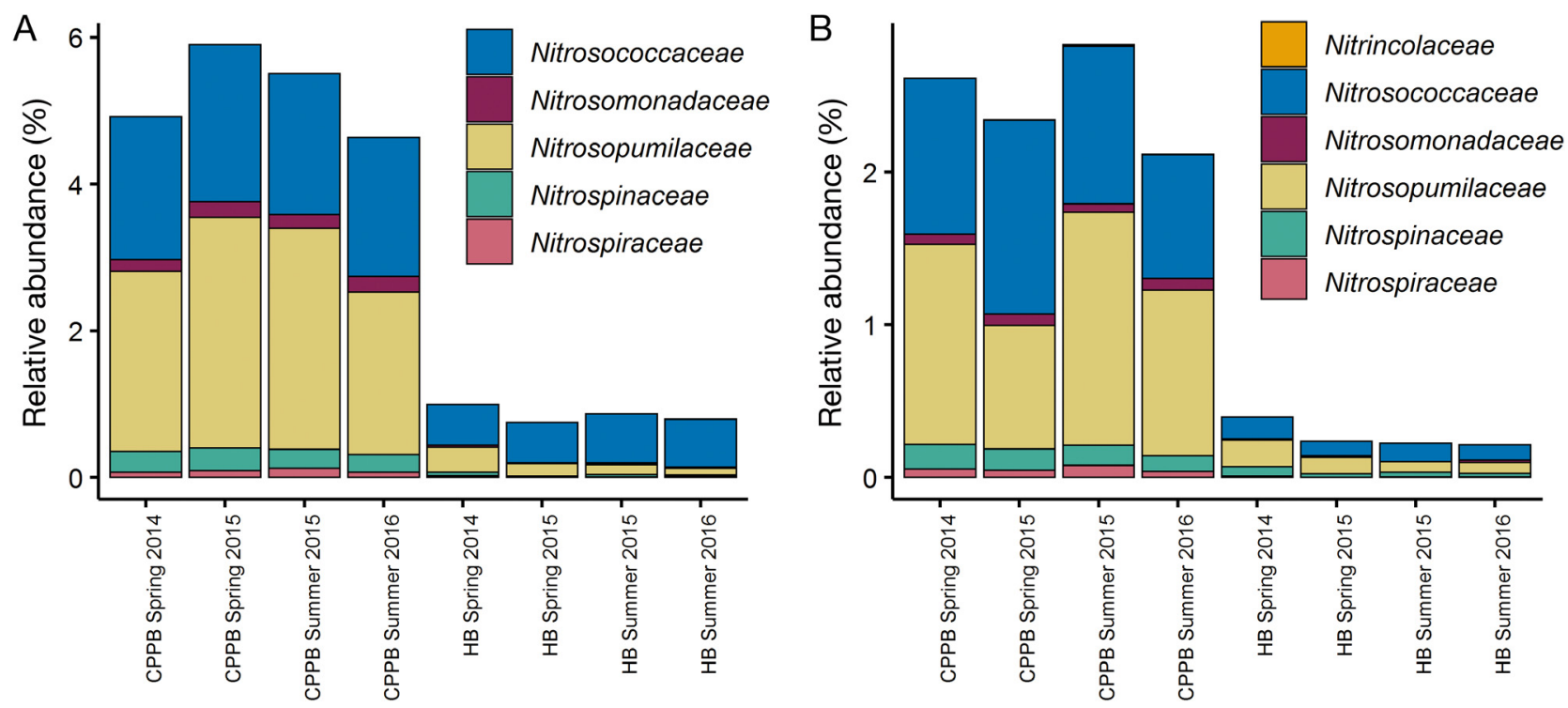

Fig. 5. Site-based differences in select nitrogen cycling taxa identified to the taxonomic level of family between Central Port Phillip Bay (CPPB) and Hobsons Bay (HB) (analysis of the composition of microbiomes [ANCOM], p $<0.05$ ) 


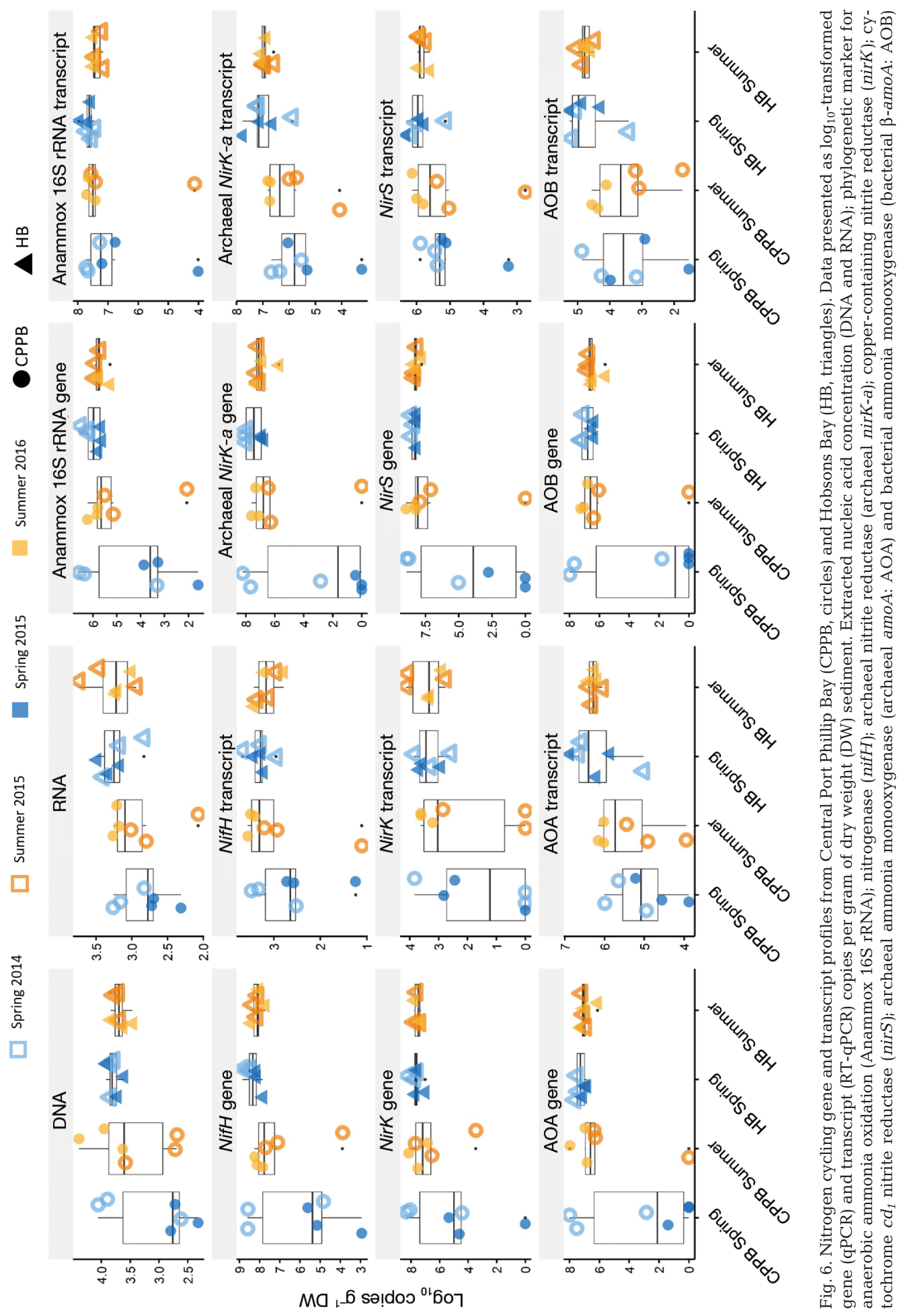


sediments displayed higher variability in the abundance of these N-cycling functional markers than HB. Except for nirS gene copies, the abundance of all measured $\mathrm{N}$-cycling genes were site-specific (ANOVA, $\mathrm{p}<0.05$; Table S3, Figs. S8 (HB) \& S9 [CPPB]). Five CPPB samples (CPPB-1C, CPPB-2B, CPPB-3A, CPPB-3B, and CPPB-3C) were identified

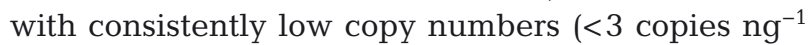
detected) across all assays. Despite comparatively high gene copy numbers, the transcript copy numbers of nifH and nirK were at or below the prescribed detection limit in all samples $\left(<3\right.$ copies $\mathrm{ng}^{-1}$ detected). Both nifH and nirk transcripts are reported here for reference, but their abundances should be interpreted with caution. The transcript copy numbers of bacterial $\beta$-amo $A$ were at or below the detection limit in $50 \%$ of the CPPB samples. All of these low copy number transcripts (nifH, nirk, bacterial $\beta$ $a m o A)$ were quantified within the generated standard curves. Except for anammox 16S rRNA and nifH transcript copies, the transcript abundance profiles of all other N-cycling genes varied between CPPB and HB surface sediments (Table S3). The gene and transcript copy numbers of archaeal amoA were higher than bacterial $\beta$-amo $A$, and the gene and transcript copies of nirS were more abundant than nirK. In all samples archaeal nirK-a gene and transcript copies were detected with transcript abundances comparable to nirS (Fig. 6, Table S3).

\subsection{Seasonal variability of the surface sediment microbial community}

Seasonal (spring vs. summer) clustering of samples were observed across PCoA2 within HB (RNA ANOSIM, $\mathrm{R}=0.32, \mathrm{p}<0.002$ and DNA ANOSIM, $\mathrm{R}=$ $0.2, p=0.01$ ), but not within CPPB (Fig. 3). One sample (HB-1C) consistently clustered separately from the site-based grouping, and when removed (RNA and DNA) along with HB-4B (DNA only) the ordination strengthened across $\mathrm{PCoA} 2$, improving the summer and spring clusters within HB (Fig. S2). Although no seasonal clustering was observed in CPPB sediments, time point-specific clustering within the active community in CPPB was observed in summer samples but not spring (Figs. 3A \& S2A).

Within each site, ANCOM identified differences in the relative abundances of taxa between spring and summer (ANCOM, $\mathrm{p}<0.05)$. Within $\mathrm{CPPB}$, the relative abundance of a single Desulfobulbales (RNA 1 ASV) ASV was higher in summer than spring (ANCOM, $\mathrm{p}<0.05$ ). In HB, a higher relative abun- dance of ASVs associated with Gammaproteobacteria family Chromatiaceaea (Candidatus Thiobios) (RNA 1 ASVs), Desulfobacteria family Desulfosarcinaceae (RNA 1 ASV, DNA 1 ASV), unclassifiable Alphaproteobacteria (RNA 1 ASVs) and a single Bacteroida family Flavobacteriaceae (DNA 1 ASV) were higher in spring than in summer communities, whereas the higher relative abundance of Planctomycetes family Pirellulaceae (RNA 1 ASV), Alphaproteobacteria family KF-JG30-B3 within the order Rhizobiales (RNA 1 ASV) and a family Kiloniellaceae (DNA 1 ASV), Gammaproteobacteria family Woeseiaceae (Woeseia) (RNA 1 ASV), unclassified Gammaproteobacteria (RNA 2 ASVs) and Nitrosococcaceae (RNA $1 \mathrm{ASV}$ ), the Acidobacteriota family Thermoanaerobaculaceae (subgroup 10) (RNA 1 ASV) and a class PS-B29 within the order Polyangia (DNA 1 ASV) were higher in summer. No significant difference was identified in either RNA- or DNA-generated libraries between spring and the following summer, e.g. spring $2014(\mathrm{n}=3)$ vs. summer $2015(\mathrm{n}=3)$, within each site or when time points were individually compared between sites.

Chloroplast plastid sequences were removed from the analysis but were identified as some of the most abundant ASVs within the active sediment community. To investigate if a seasonal signal exists within this fraction of the community, reads annotated as Chloroplasts at the order level (68 ASVs; $2.2 \%$ of the diversity and $4 \%$ of the total read count) were analysed (Fig. S10). Replacing these reads improved the amount of variation explained by the second axis from $10.1 \%$ (Fig. 3A) to $21.2 \%$ (Fig. S10A) and improved the structuring of seasonal based community clusters within HB (RNA ANOSIM, R = 0.79, p < 0.01; Fig. S10A). Replacing these reads had little impact on the active community structure between spring and summer in CPPB. When isolated from the active community, these chloroplast sequences displayed season-specific structuring in $\mathrm{HB}$ but not $\mathrm{CPPB}$ (Fig. S10B).

For all N-cycling genes measured, the CPPB spring samples displayed the most variability in abundances whereas summer samples showed less variability and had similar abundances to HB samples. This site-specific variability was introduced by 5 samples (CPPB-1C, CPPB-2B, CPPB-3A, CPPB-3B, and $\mathrm{CPPB}-3 \mathrm{C}$ ) each with low copy numbers and was the most pronounced in low copy number functional markers (archaeal nirk-a, archaeal amoA, nirS, bacterial $\beta$-amoA). Within HB sediments, anammox $16 \mathrm{~S}$ rRNA gene and transcript abundances significantly decreased from spring to summer (Season $F_{[1,8]}=$ 
7.2-11.6, $\mathrm{p}<0.05$; Fig. S8). Within HB, the abundances of bacterial $\beta$-amoA, anammox 16S rRNA, archaeal nirK-a and nifH genes (Date $F_{[1,8]}=4.5-5$, $\mathrm{p}<0.05)$ and the transcript abundance of anammox 16S rRNA varied by sampling dates (Date $F_{[1,8]}=5.6$, $\mathrm{p}<0.05$ ), with no interaction effect identified between season and date sampled. Within $\mathrm{CPPB}$, no significant differences were identified by season or date sampled. Within CPPB a significant interaction was identified between season and sampling date, most likely driven by the 5 low abundance samples (Figs. 6 \& S8 [HB] and Fig. S9 [CPPB]).

\section{DISCUSSION}

PPB can be characterised by its globally high denitrification efficiencies which have been attributed to low external carbon loading and the unique physical attributes of its large central basin (Harris et al. 1996, Berelson et al. 1998, 1999, Murray \& Parslow 1999, Eyre \& Ferguson 2009). Within this system, benthic recycling of $\mathrm{N}_{\mathrm{r}}$ to the water column provides an estimated $63 \%$ of the $\mathrm{N}_{\mathrm{r}}$-input with nutrient regeneration by the sediments 3-30 times greater in the northern end (HB) close to the Yarra River estuary than in the centre (CPPB) (Berelson et al. 1998). By characterising the sediment microbial community at these 2 contrasting sites, we show that CPPB sediments can also be characterised by a seasonally stable microbial community, which can be differentiated from HB sediments by a higher relative abundance of microbial taxa with chemoautotrophic metabolisms and site-specific nitrifiers. By measuring N-cycling transcript profiles, we show that despite the historically lower and seasonally more variable denitrification efficiencies of HB sediments, these communities are consistently engaging in diverse N-cycling processes across seasons despite $\mathrm{N}$-cycling taxa contributing less to the overall community composition.

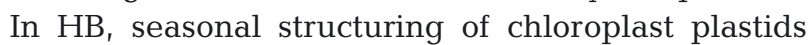
was identified, corroborating seasonal impacts of phytoplankton or phytodetritus at this site. Within these sediments, decreases in gene abundance and activity profiles of anammox bacteria were also identified in conjunction with decreases in organic carbon content from spring to summer. The contribution of anammox to $\mathrm{N}_{\mathrm{r}}$-loss (Dalsgaard \& Thamdrup 2002) has not been previously incorporated into benthic flux estimates within these sediments, and seasonal changes to the functional capacity of this community may lead to reductions in denitrification efficiencies. We found no evidence to support seasonally uncou- pled nitrification-denitrification based on changes in $\mathrm{N}$-cycling transcript abundances or decreases in $\mathrm{N}$ cycling taxa. By comparison, in CPPB the lower and more variable $\mathrm{N}$-cycling gene abundances and activity profiles, especially in spring samples, may imply that transient engagement in microbial $\mathrm{N}$-cycling processes is occurring in these isolated sediments, with the majority of the heavy lifting to remove $\mathrm{N}_{\mathrm{r}}$ occurring closer to sediment regions with less efficient denitrification estimates and higher $\mathrm{N}_{\mathrm{r}}$ regeneration rates.

\subsection{Spatial differences in sediment microbial community composition and $\mathrm{N}$-cycling capacity}

The central basin of PPB represents an $800 \mathrm{~km}^{2}$ region or $\sim 70 \%$ of this coastal system and is an area of historically high denitrification efficiencies, high bioirrigation rates, and nutrient limitation (Harris et al. 1996, Berelson et al. 1998, 1999, Murray \& Parslow 1999). We have shown that when compared to HB where nutrient regeneration is 3-30 times higher (Berelson et al. 1998), the microbial community of these nutrient-limited CPPB sediments are enriched in sediment microbial taxa known to support chemoautotrophic growth. Specifically, these sediments have a higher relative abundance of known chemoautotrophic $\mathrm{N}$-cycling taxa (e.g. Nitrosopumiales and Nitrosococcales) (Martens-Habbena et al. 2009) and sulfate-reducing bacteria capable of anaerobic degradation of diverse organic materials including nalkanes (e.g. Desulfobacteria family Desulfosarcinacea) (Watanabe et al. 2017). The Desulfobacteria are mesophilic sulfate-reducing bacteria with members shown to use catechol, the intermediary product of anaerobic degradation of plant material, to perform dissimilatory reduction of nitrate to ammonium (Szewzyk \& Pfennig 1987). In these isolated CPPB sediments a consortia of nitrifiers coupled with sulfate-reducing bacteria could drive the highly efficient denitrification efficiencies that define this region (Berelson et al. 1998). The higher relative abundance of Desulfobacteria in CPPB sediments supports an earlier report of higher relative abundance of the fatty acid biomarker 10Me16:0 associated with Desulfobacter in these sediments (O'Leary et al. 1994). The BD7-8 marine group, commonly identified as symbionts of marine invertebrates and more recently associated with increased bioirrigation rates (Deng et al. 2020), were also comparatively higher in CPPB than HB sediments, and their higher relative abundance could potentially reflect the 
higher moisture content measured at this site within this study. The comparatively higher organic carbon content and lower TOC:N in CPPB sediments supports previous research that the central basin is a sink for organic matter due to the deposition of phytoplankton (O'Leary et al. 1994, Volkman et al. 1999). Selection of chemoautotrophic taxa at this site coupled with the lack of chloroplast plastids within the active community could imply that accessing this organic matter within CPPB requires more specialised metabolisms than in HB sediments, where the type of organic carbon could also be more labile. The sediments of $\mathrm{HB}$ are within close proximity to PPBs primary estuary the Yarra River, which is the primary external source of $\mathrm{N}_{\mathrm{r}}$ to this system (Harris et al. 1996). These sediments were characterised by a higher relative abundance of taxa associated with primary production (e.g. Chloroplasts plastids and the aerobic photoheterotroph Cellvibrionales family Halieaceae) (Spring et al. 2015), the breakdown of high-molecular-weight compounds (e.g. Flavorbacteriales, Bacteroidales and Fusobacteriales) (Teeling et al. 2012), sulphur oxidation coupled to the $\mathrm{N}_{\mathrm{r}}$ retention pathway dissimilatory nitrate reduction to ammonium (e.g. Desulfobulbaceae) (Robertson et al. 2016), anaerobic conditions and potentially lower sediment permeability (e.g. Ectothiorhodospiraceae and Flavobacteriaceae) (Probandt et al. 2017). These taxonomic differences likely reflect the higher light attenuation of this shallower site and the constant stream of organic material and nutrient inputs that are delivered to these sediments from the Yarra River (Harris et al. 1996). Known drivers of microbial community composition $(\mathrm{pH}$, moisture content, organic carbon and $\mathrm{N}$ content, chlorophyll $\alpha$ and $\mathrm{NH}_{4}{ }^{+} \mathrm{-N}$ ) (Jorgensen et al. 2012, Fortunato et al. 2013, Fagervold et al. 2014, Probandt et al. 2017, Wang et al. 2018, Liu et al. 2019) varied between these sampling sites, and in conjunction with previous research our study supports the findings that $\mathrm{HB}$ and CPPB represent both biogeochemically (Murray \& Parslow 1999) and microbial distinct sediment habitats.

The ammonia-oxidising archaeal taxa Nitrosopumiales and the ammonia-oxidising bacterial taxa Nitrosococcales were amongst the most abundant taxa within the active microbial community in PPB. Both taxa were comparatively more abundant in $\mathrm{CPPB}$, based on the relative abundance of single taxonomic representatives (Nitrosopumiales ASV_6 and Nitrosococcales ASV_13). Spatial differences in these 2 highly abundant nitrifier ASVs could indicate that local environmental gradients are selecting for nitrifier ecotypes within PPB. The presence of site-spe- cific nitrifier representatives is supported by our previous observations that amoA primer choice impacted our interpretation of archaeal nitrifier gene depth profiles in CPPB but had no impact in $\mathrm{HB}$ (Marshall et al. 2018). Nitrifier ecotypes have been suggested based on global distribution patterns of ammonia-oxidising archaea and bacteria coupled to habitat type, ammonia concentration, light availability and environmental conditions (Biller et al. 2012, Sintes et al. 2016). Environmental gradients are known to vary across PPB (Harris et al. 1996, present study) with 8 distinct sediment regions predicted based on spatial patterns in the observations of nutrient pools and fluxes (Murray \& Parslow 1999). Whether these distinct sediment regions have equally distinct microbial or nitrifier community compositions is of interest to improve the resolution of coastal nutrient monitoring programs especially since water within PPB has a long residence time (>1 yr) (Harris et al. 1996), and nitrifiers are implicated in the production of the greenhouse gas nitrous oxide $\left(\mathrm{N}_{2} \mathrm{O}\right)$ (Nevison et al. 2003).

Despite the high proportion of Nitrosococcaceae within these sediments, the low transcript abundances of Nitrosococcaceae associated $\beta$-amoA and nirK (Klotz et al. 2006), combined with the higher abundance of transcripts associated with archaeal amo $A$ and archaeal nirk-a, supports a system functionally dominated by archaeal nitrifiers. This finding agrees with previous global coastal studies where archaeal nitrifiers were more abundant (Abell et al. 2010, Beman et al. 2012) and adds to this body of research by providing temporal activity profiles of both archaeal amoA and archaeal nirk-a.

\subsection{Seasonal differences in sediment microbial community composition and $\mathrm{N}$-cycling capacity}

The dominance of archaeal to bacterial nitrifiers inferred from gene abundances has been shown to vary with spatial and temporal variability in oxygen, $\mathrm{NH}_{4}{ }^{+}, \mathrm{NO}_{2}{ }^{-}$, light, organic carbon, $\mathrm{pH}$, temperature and salinity gradients (Abell et al. 2010, Bouskill et al. 2012). The CPPB sediments were found to have higher carbon content and $\mathrm{pH}$ compared to $\mathrm{HB}$, but HB experiences higher variability in salinity concentrations due to sporadic freshwater runoff events from the Yarra River (Longmore 2015, 2016). Therefore, we might expect to see lower abundances in HB coupled to carbon and $\mathrm{pH}$, and more variability in the proportion of archaeal amoA and bacterial $\beta$ amo $A$ sequences in $\mathrm{HB}$ associated with seasonally 
variable freshwater inflow events. Yet we identified comparatively higher transcript abundances associated with archaeal $a m o A$ and bacterial $\beta$-amo $A$ in HB than CPPB and found no evidence to suggest that seasonal decreases in the abundance of nitrifier transcripts occur at either site.

Seasonal decreases in denitrification efficiencies in PPB sediments are coupled to the increased deposition of phytodetritus from the water column onto the sediment surface, which stimulates microbial carbon decomposition rates, depleting the sediments of oxygen, uncoupling nitrification-denitrification (Harris et al. 1996, Berelson et al. 1998). Within this study we demonstrated that seasonal structuring of the active microbial community composition in HB is strengthened by changes in the relative abundance of chloroplast plastid sequences associated with phytoplankton. These sequences may represent changes in deposition of phytodetritus or the abundance of sediment dwelling microphytobenthos (RisgaardPetersen 2003). Despite the biological source of these sequences we found no strong evidence to suggest that the capacity for the microbial nitrifier community to perform nitrification changed in conjunction with community compositional changes in $\mathrm{HB}$ between spring and summer. The lack of seasonal structuring in the archaeal nitrifier community supports previous temporal research (Yazdani Foshtomi et al. 2015) but could also be indicative of the relative importance of nitrification to the microbial community in these sediments. These HB sediments are proximal to external inputs into PPB via the Yarra River, and higher $\mathrm{CO}_{2}$ flux coupled with higher $\mathrm{O}_{2}$ consumption by the sediment at this site may indicate that nitrification when compared to other processes (e.g. sulfate reduction) is not the dominant coastal microbial process (Dyksma et al. 2016).

Despite little seasonal change in the abundance and activity profiles of functional genes associated with the nitrifier community, evidence for a seasonal decrease from spring to summer in the abundance of the phylogenetic marker associated with anammox bacteria was identified within HB and occurred in conjunction with a seasonal decrease in organic carbon content. Low sulphide concentrations (>0.32 mM), and high concentrations of ammonia (>44 mM) and nitrite (>7.4 mM) have been identified as inhibitors for anammox (Carvajal-Arroyo et al. 2013), while cooler temperatures and lower ratios of TOC:N have been suggested to favour anammox processes (Devol 2015, Babbin et al. 2016). Within this study the temperature of the bottom water was within optimal ranges for anammox (18-21 ${ }^{\circ} \mathrm{C}$ ) (Tan et al. 2020), and we did not identify any seasonal changes in the concentration of sediment or pore-water $\mathrm{NH}_{4}{ }^{+}$or $\mathrm{NO}_{\mathrm{x}}$. A decrease in organic carbon content and the TOC:N was observed from spring to summer in these sediments, which we might expect to select for anammox, not against. Yet, we did not measure the type of organic carbon or the concentration of sulphides, which may have impacted this community in summer months. The availably of organic carbon and the TOC:N have been shown to impact how anammox bacteria interact with the N-cycle. Increased organic carbon concentrations inhibit anammox and lower TOC:N favour community level-coupled DNRAanammox between nitrifiers (ammonium- and nitriteoxidising bacteria) and anammox bacteria over heterotrophic denitrification-anammox (Kartal et al. 2007, Castro-Barros et al. 2017). Less than $1 \%$ of sediment $\mathrm{N}_{\mathrm{r}}$-loss processes could be attributed to anammox within the fresh and brackish regions of the Yarra River (Roberts et al. 2012). However, the role for annamox-driven $\mathrm{N}_{\mathrm{r}}$-loss processes increasing the denitrification efficiency in more marine impacted HB sediments in spring and a reduction in this pathway impacting these metrics in summer has not been previously considered in this system.

Within HB, conflicting evidence that N-cycling pathways increased from spring to summer were also identified. An increased abundance of single ASVs associated with the bacterial nitrifiers Nitrosococcaceae (Klotz et al. 2006), anaerobic ammonia-oxidising bacteria Pirellulaceae (Mohamed et al. 2010) and denitrifiers within Kiloniellaceae (Wiese et al. 2020) and Woeseiaceae (Mußmann et al. 2017) were identified. These contrasting changes were further complicated by time point-specific variation in the abundance of bacterial ammonium monooxygenase (bacterial $\beta$-amoA), archaeal nitrite reductase (nirk-a), anammox 16S rRNA and nitrogenase (nifH) gene copies at this site. These taxonomic and functional gene changes represent vastly different processes within the microbial $\mathrm{N}$-cycle, and their variability in HB but not within CPPB may be indicative of variation in how the community cycles $\mathrm{N}$ at this site as it changes community composition between the spring and summer.

Benthic $\mathrm{N}_{2}$-fixation has been identified in coastal sediments (Bertics et al. 2013) and has been measured under environmental conditions previously thought to select against $\mathrm{N}_{2}$-fixation (high $\mathrm{NO}_{3}{ }^{-}$up to $30 \mu \mathrm{M}$ and/or high $\mathrm{NH}_{4}+$ up to $200 \mu \mathrm{M}$ ) (Knapp 2012). We identified seasonal shifts in the relative abundances of non-cyanobacterial diazotrophs (e.g. Chromatiaceae and Desulfosarcinacea) (Bombar et 
al. 2016), though for the functional gene assays nifH gene copies were high in abundance while nifH activity (RNA) were at or below the assay detection limit. Estimates of coastal sediment $\mathrm{N}_{2}$-fixation are low $\left(0.002-0.65 \mathrm{~N} \mathrm{~m}^{-2} \mathrm{yr}^{-1}\right)$ with the highest rates measured in sediments with high organic content (see references in Herbert 1999). High nifH gene copy numbers may overestimate the role of $\mathrm{N}_{2}$-fixation in sediments with transcript copies, providing a more accurate reflection of the contribution of this group to sediment $\mathrm{N}$-budgets. One alternative explanation for the discrepancy between gene and transcript abundances measured here is that we sampled during the day while sediment diazotrophs could be transcribing nifH at night within the early morning hours as $\mathrm{N}_{2}$-fixation is sensitive to oxygen (Harke et al. 2019). The contribution of the diazotroph community to nitrogen cycling within these sediments and their seasonal impact on denitrification efficiencies have not been previously considered.

Our lack of evidence to support the role of seasonally uncoupled nitrification-denitrification leading to variability in denitrification efficiency within HB sediments could also be a reflection of high natural heterogeneity within these metrics. During this study the benthic flux denitrification efficiency decreased from spring 2014 to summer 2015 as expected due to changes in the flux of $\mathrm{N}_{2}$ from the sediment, but no decrease occurred between spring 2015 and summer 2016. Inconsistency in the seasonal flux in spring 2015 to summer 2016 may have additionally added a confounding factor to our interpretation. Coupling benthic flux to measures of microbial activity in environmental settings is difficult especially over restricted sampling time points. More frequent or longer-term sampling would be required to elucidate if the trends identified in this preliminary assessment hold over time.

\section{CONCLUSION}

In $\mathrm{PPB}$, the composition of the sediment microbial community and the abundance and activity profiles of key $\mathrm{N}$-cycling genes were specific to each location sampled, reflecting their unique sediment environments (Harris et al. 1996, Murray \& Parslow 1999). Only within the HB sediments which are located close to inputs into PPB via the Yarra River did we identify changes in the composition of the microbial community profiles when comparing seasons (spring vs. summer), as well as seasonal and date-specific signatures in the abundance of both $\mathrm{N}$-cycle genes and transcripts. In contrast, CPPB sediments which are furthest from inputs into PPB showed no evidence of seasonal-specific structuring of the microbial community. Together, these findings improve our understanding of how seasonality and proximity to estuaries govern changes in the sediment environment and the interconnectedness between $\mathrm{N}$-flux and the microbial taxa that perform these functions. To our knowledge, this study is the first to report evidence of the spatial variation in the composition of the sediment microbial community within the PPB system and to identify that seasonal variation in microbial community composition occurs in HB where the denitrification efficiency is also known to vary, but not $\mathrm{CPPB}$ where the denitrification efficiency is more stable. Despite seasonal community compositional changes in $\mathrm{HB}$, we identified that these structural changes were uncoupled from this community's capacity to cycle $\mathrm{N}$ via nitrification-denitrification but potentially associated with alternative dissimilarity $\mathrm{N}_{\mathrm{r}}$-loss pathways coupled to anammox.

Acknowledgements. We thank George Croato for assistance with analysing pore-water nitrogen concentrations. This work was supported by Melbourne Water, the Victorian Department of Environment, Land, Water and Planning (DELWP) and the Victorian Department of Jobs, Precincts and Regions (DJPR; Agriculture Victoria Research). The manuscript was written while K.B.H. was serving at the National Science Foundation. Any opinion, findings, and conclusions or recommendations expressed in this material are those of the authors and do not necessarily reflect the views of the National Science Foundation. This study was supported by an investment proposal to Melbourne Water and the Victorian Department of Environment, Land, Water and Planning.

\section{LITERATURE CITED}

Abell GCJ, Revill AT, Smith C, Bissett AP, Volkman JK, Robert SS (2010) Archaeal ammonia oxidizers and nirStype denitrifiers dominate sediment nitrifying and denitrifying populations in a subtropical macrotidal estuary. ISME J 4:286-300

Altschul SF, Gish W, Miller W, Myers EW, Lipman DJ (1990) Basic local alignment search tool. J Mol Biol 215:403-410

*An S, Gardner WS (2002) Dissimilatory nitrate reduction to ammonium (DNRA) as a nitrogen link, versus denitrification as a sink in a shallow estuary (Laguna Madre/Baffin Bay, Texas). Mar Ecol Prog Ser 237:41-50

Andrews S (2012) FastQC: a quality control tool for high throughput sequence data. www.bioinformatics.babra ham.ac.uk/projects/fastqc/

Angly FE, Heath C, Morgan TC, Tonin H and others (2016) Marine microbial communities of the Great Barrier Reef lagoon are influenced by riverine floodwaters and seasonal weather events. PeerJ 4:e1511 
Babbin AR, Jayakumar A, Ward BB (2016) Organic matter loading modifies the microbial community responsible for nitrogen loss in estuarine sediments. Microb Ecol 71: 555-565

Beman JM, Bertics VJ, Braunschweiler T, Wilson J (2012) Quantification of ammonia oxidation rates and the distribution of ammonia-oxidizing archaea and bacteria in marine sediment depth profiles from Catalina Island, California. Front Microbiol 3:263

Berelson WM, Heggie D, Longmore A, Kilgore T, Nicholson G, Skyring G (1998) Benthic nutrient recycling in Port Phillip Bay, Australia. Estuar Coast Shelf Sci 46:917-934

Berelson WM, Townsend T, Heggie D, Ford P and others (1999) Modelling bio-irrigation rates in the sediments of Port Phillip Bay. Mar Freshw Res 50:573-579

Bertics VJ, Sohm JA, Treude T, Chow CET, Capone DG, Fuhrman JA, Ziebis W (2010) Burrowing deeper into benthic nitrogen cycling: the impact of bioturbation on nitrogen fixation coupled to sulfate reduction. Mar Ecol Prog Ser 409:1-15

Bertics VJ, Löscher CR, Salonen I, Dale AW, Gier J, Schmitz RA, Treude T (2013) Occurrence of benthic microbial nitrogen fixation coupled to sulfate reduction in the seasonally hypoxic Eckernförde Bay, Baltic Sea. Biogeosciences 10:1243-1258

Biller SJ, Mosier AC, Wells GF, Francis CA (2012) Global biodiversity of aquatic ammonia-oxidizing archaea is partitioned by habitat. Front Microbiol 3:252

Böer SI, Hedtkamp SIC, van Beusekom JEE, Fuhrman JA, Boetius A, Ramette A (2009) Time- and sediment depthrelated variations in bacterial diversity and community structure in subtidal sands. ISME J 3:780-791

Bokulich NA, Subramanian S, Faith JJ, Gevers D and others (2013) Quality-filtering vastly improves diversity estimates from Illumina amplicon sequencing. Nat Methods 10:57-59

Bolger AM, Lohse M, Usadel B (2014) Trimmomatic: a flexible trimmer for Illumina sequence data. Bioinformatics 30:2114-2120

* Bombar D, Paerl RW, Riemann L (2016) Marine non-cyanobacterial diazotrophs: moving beyond molecular detection. Trends Microbiol 24:916-927

Bouskill NJ, Eveillard D, Chien D, Jayakumar A, Ward BB (2012) Environmental factors determining ammoniaoxidizing organism distribution and diversity in marine environments. Environ Microbiol 14:714-729

Braker G, Fesefeldt A, Witzel KP (1998) Development of PCR primer systems for amplification of nitrite reductase genes (nirK and nirS) to detect denitrifying bacteria in environmental samples. Appl Environ Microbiol 64: 3769-3775

Bustin SA, Benes V, Garson JA, Hellemans J and others (2009) The MIQE guidelines: minimum information for publication of quantitative real-time PCR experiments. Clin Chem 55:611-622

* Callahan BJ, McMurdie PJ, Rosen MJ, Han AW, Johnson AJA, Holmes SP (2016) DADA2: high-resolution sample inference from Illumina amplicon data. Nat Methods 13: 581-583

* Caporaso JG, Lauber CL, Walters WA, Berg-Lyons D and others (2012) Ultra-high-throughput microbial community analysis on the Illumina HiSeq and MiSeq platforms. ISME J 6:1621-1624

* Carvajal-Arroyo JM, Sun W, Sierra-Alvarez R, Field JA (2013) Inhibition of anaerobic ammonium oxidizing (anammox) enrichment cultures by substrates, metabolites and common wastewater constituents. Chemosphere 91:22-27

* Castro-Barros CM, Jia M, van Loosdrecht MCM, Volcke EIP, Winkler MKH (2017) Evaluating the potential for dissimilatory nitrate reduction by anammox bacteria for municipal wastewater treatment. Bioresour Technol 233: 363-372

* Dalsgaard T, Thamdrup B (2002) Factors controlling anaerobic ammonium oxidation with nitrite in marine sediments. Appl Environ Microbiol 68:3802-3808

* Deng L, Bölsterli D, Kristensen E, Meile C and others (2020) Macrofaunal control of microbial community structure in continental margin sediments. Proc Natl Acad Sci 117: 15911-15922

* Devol AH (2015) Denitrification, anammox, and $\mathrm{N}_{2}$ production in marine sediments. Annu Rev Mar Sci 7:403-423

* Dickson AG (1981) An exact definition of total alkalinity and a procedure for the estimation of alkalinity and total inorganic carbon from titration data. Deep-Sea Res Part Oceanogr Res Pap 28:609-623

* Dixon P (2003) VEGAN, a package of R functions for community ecology. J Veg Sci 14:927-930

*Dyksma S, Bischof K, Fuchs BM, Hoffmann K and others (2016) Ubiquitous Gammaproteobacteria dominate dark carbon fixation in coastal sediments. ISME J 10:1939-1953

* Edgar RC (2004a) MUSCLE: a multiple sequence alignment method with reduced time and space complexity. BMC Bioinformatics 5:113

*Edgar RC (2004b) MUSCLE: multiple sequence alignment with high accuracy and high throughput. Nucleic Acids Res 32:1792-1797

Eyre BD, Ferguson AJP (2009) Denitrification efficiency for defining critical loads of carbon in shallow coastal ecosystems. Hydrobiologia 629:137-146

Fagervold SK, Bourgeois S, Pruski AM, Charles F, Kerhervé P, Vétion G, Galand PE (2014) River organic matter shapes microbial communities in the sediment of the Rhône prodelta. ISME J 8:2327-2338

Faith DP (1992) Conservation evaluation and phylogenetic diversity. Biol Conserv 61:1-10

*Fortunato CS, Herfort L, Zuber P, Baptista AM, Crump BC (2012) Spatial variability overwhelms seasonal patterns in bacterioplankton communities across a river to ocean gradient. ISME J 6:554-563

Fortunato CS, Eiler A, Herfort L, Needoba JA, Peterson TD, Crump BC (2013) Determining indicator taxa across spatial and seasonal gradients in the Columbia River coastal margin. ISME J 7:1899-1911

* Gilbert F, Hulth S, Grossi V, Aller RC (2016) Redox oscillation and benthic nitrogen mineralization within burrowed sediments: an experimental simulation at low frequency. J Exp Mar Biol Ecol 482:75-84

Greilach P (1996) Sediment characteristics in Port Phillip Bay. CSIRO Environmental Projects Office, Yarralumla

*Harke MJ, Frischkorn KR, Haley ST, Aylward FO, Zehr JP, Dyhrman ST (2019) Periodic and coordinated gene expression between a diazotroph and its diatom host. ISME J 13:118-131

Harris G, Batley G, Fox D, Hall D and others (1996) Port Phillip environmental study final report. CSIRO, Dickson

*Heggie DT, Skyring GW, Orchardo J, Longmore AR, Nicholson GJ, Berelson WM (1999) Denitrification and denitrifying efficiencies in sediments of Port Phillip Bay: direct determinations of biogenic $\mathrm{N}_{2}$ and $\mathrm{N}$-metabolite fluxes 
with implications for water quality. Mar Freshw Res 50: 589-596

Herbert RA (1999) Nitrogen cycling in coastal marine ecosystems. FEMS Microbiol Rev 23:563-590

Holdgate GR, Geurin B, Wallace MW, Gallagher SJ (2001) Marine geology of Port Phillip, Victoria. Aust J Earth Sci 48:439-455

Illumina (2013) 16S metagenomic sequencing library preparation. www.illumina.com/content/dam/illumina-support/ documents/documentation/chemistry_documentation/ 16s/16s-metagenomic-library-prep-guide-15044223-b. pdf (accessed 16 Dec 2016)

Jeffries TC, Schmitz Fontes ML, Harrison DP, Van-DongenVogels V, Eyre BD, Ralph PJ, Seymour JR (2016) Bacterioplankton dynamics within a large anthropogenically impacted urban estuary. Front Microbiol 6:1438

Jones ZL, Jasper JT, Sedlak DL, Sharp JO (2017) Sulfideinduced dissimilatory nitrate reduction to ammonium supports anaerobic ammonium oxidation (anammox) in an open-water unit process wetland. Appl Environ Microbiol 83:e00782-e17

* Jorgensen SL, Hannisdal B, Lanzén A, Baumberger T and others (2012) Correlating microbial community profiles with geochemical data in highly stratified sediments from the Arctic Mid-Ocean Ridge. Proc Natl Acad Sci USA 109:E2846-E2855

Kana TM, Sullivan MB, Cornwell JC, Groxzkowski KM (1998) Denitrification in estuarine sediments determined by membrane inlet mass spectrometry. Limnol Oceanogr 43:334-339

Kartal B, Kuypers MMM, Lavik G, Schalk J, Op den Camp HJM, Jetten MSM, Strous M (2007) Anammox bacteria disguised as denitrifiers: nitrate reduction to dinitrogen gas via nitrite and ammonium. Environ Microbiol 9: 635-642

Kembel SW, Cowan PD, Helmus MR, Cornwell WK and others (2010) Picante: $R$ tools for integrating phylogenies and ecology. Bioinformatics 26:1463-1464

Kessler AJ, Roberts KL, Bissett A, Cook PLM (2018) Biogeochemical controls on the relative importance of denitrification and dissimilatory nitrate reduction to ammonium in estuaries. Glob Biogeochem Cycles 32:1045-1057

Klotz MG, Arp DJ, Chain PSG, El-Sheikh AF and others (2006) Complete genome sequence of the marine, chemolithoautotrophic, ammonia-oxidizing bacterium Nitrosococcus oceani ATCC 19707. Appl Environ Microbiol 72: 6299-6315

Knapp AN (2012) The sensitivity of marine $\mathrm{N}_{2}$ fixation to dissolved inorganic nitrogen. Front Microbiol 3:374

Kozich JJ, Westcott SL, Baxter NT, Highlander SK, Schloss PD (2013) Development of a dual-index sequencing strategy and curation pipeline for analyzing amplicon sequence data on the MiSeq Illumina sequencing platform. Appl Environ Microbiol 79:5112-5120

Kuypers MMM, Marchant HK, Kartal B (2018) The microbial nitrogen-cycling network. Nat Rev Microbiol 16: 263-276

Li M, Hong Y, Klotz MG, Gu JD (2010) A comparison of primer sets for detecting 16S rRNA and hydrazine oxidoreductase genes of anaerobic ammonium-oxidizing bacteria in marine sediments. Appl Microbiol Biotechnol 86:781-790

Liu Y, Debeljak P, Rembauville M, Blain S, Obernosterer I (2019) Diatoms shape the biogeography of heterotrophic prokaryotes in early spring in the Southern Ocean.
Environ Microbiol 21:1452-1465

Longmore AR (2015) Port Phillip Bay environmental management plan nutrient monitoring annual report 2014-2015. Centre for Aquatic Pollution Identification and Mangement, The University of Melbourne, Melbourne

Longmore AR (2016) Port Phillip Bay environmental management plan nutrient monitoring annual report 2015-2016. Centre for Aquatic Pollution Identification and Mangement, The University of Melbourne, Melbourne

Longmore AR, Nicholson GJ (2012) Port Phillip Bay Environmental Management Plan: monitoring the state of the Bay nutrient cycling (2002-2011). Department of Primary Industries, Queenscliff

* Lund MB, Smith JM, Francis CA (2012) Diversity, abundance and expression of nitrite reductase (nirK)-like genes in marine thaumarchaea. ISME J 6:1966

Magro KL, Arnott GH, Hill DRA (1996) Algal blooms in Port Phillip Bay from March 1990 to February 1995: temporal and spatial distribution and dominant species. CSIRO Port Phillip Bay Environmental Study, Melbourne

Mandal S, Van Treuren W, White RA, Eggesbø M, Knight R, Peddada SD (2015) Analysis of composition of microbiomes: a novel method for studying microbial composition. Microb Ecol Health Dis 26:27663

* Marshall A, Phillips L, Longmore A, Tang C, Heidelberg K, Mele P (2018) Primer selection influences abundance estimates of ammonia oxidizing archaea in coastal marine sediments. Mar Environ Res 140:90-95

* Martens-Habbena W, Berube PM, Urakawa H, de la Torre JR, Stahl DA (2009) Ammonia oxidation kinetics determine niche separation of nitrifying archaea and bacteria. Nature 461:976-979

Martin M (2011) Cutadapt removes adapter sequences from high-throughput sequencing reads. EMBnet.journal 17: 10-12

Mohamed NM, Saito K, Tal Y, Hill RT (2010) Diversity of aerobic and anaerobic ammonia-oxidizing bacteria in marine sponges. ISME J 4:38-48

* Murray AG, Parslow JS (1999) Modelling of nutrient impacts in Port Phillip Bay - a semi-enclosed marine Australian ecosystem. Mar Freshw Res 50:597-612

*Mußmann M, Pjevac P, Krüger K, Dyksma S (2017) Genomic repertoire of the Woeseiaceae/JTB255, cosmopolitan and abundant core members of microbial communities in marine sediments. ISME J 11:1276-1281

Nevison C, Butler JH, Elkins JW (2003) Global distribution of $\mathrm{N}_{2} \mathrm{O}$ and the $\Delta \mathrm{N}_{2} \mathrm{O}$-AOU yield in the subsurface ocean. Glob Biogeochem Cycles 17:30-31

O'Leary T, Leeming R, Nichols PD, Volkman JK (1994) The distributions and concentrations of biomarkers for sewage, primary producers and bacteria in the major sediment types of Port Phillip Bay. CSIRO, Hobart, TAS

* Parada AE, Needham DM, Fuhrman JA (2016) Every base matters: assessing small subunit rRNA primers for marine microbiomes with mock communities, time series and global field samples. Environ Microbiol 18:1403-1414

Parsons T, Maita Y, Lalli C (1984) A manual of chemical and biological methods for seawater analysis. Pergamon, Oxford

*Pobandt D, Knittel K, Tegetmeyer HE, Ahmerkamp S, Holtappels M, Amann R (2017) Permeability shapes bacterial communities in sublittoral surface sediments. Environ Microbiol 19:1584-1599

Quast C, Pruesse E, Yilmaz P, Gerken J and others (2013) The SILVA ribosomal RNA gene database project: 
improved data processing and web-based tools. Nucleic Acids Res 41:D590-D596

R Core Team (2014) R: a language and environment for statistical computing. R Foundation for Statistical Computing, Vienna. www.R-project.org

Ren L, Song X, He D, Wang J and others (2019) Bacterioplankton metacommunity processes across thermal gradients: weaker species sorting but stronger niche segregation in summer than in winter in a subtropical bay. Appl Environ Microbiol 85:e02088-18

Risgaard-Petersen N (2003) Coupled nitrification-denitrification in autotrophic and heterotrophic estuarine sediments: on the influence of benthic microalgae. Limnol Oceanogr 48:93-105

Roberts KL, Eate VM, Eyre BD, Holland DP, Cook PLM (2012) Hypoxic events stimulate nitrogen recycling in a shallow salt-wedge estuary: the Yarra River estuary, Australia. Limnol Oceanogr 57:1427-1442

Robertson EK, Roberts KL, Burdorf LDW, Cook P, Thamdrup B (2016) Dissimilatory nitrate reduction to ammonium coupled to $\mathrm{Fe}(\mathrm{II})$ oxidation in sediments of a periodically hypoxic estuary. Limnol Oceanogr 61:365-381

Robinson MD, McCarthy DJ, Smyth GK (2010) EdgeR: a Bioconductor package for differential expression analysis of digital gene expression data. Bioinformatics 26: 139-140

Rösch C, Mergel A, Bothe H (2002) Biodiversity of denitrifying and dinitrogen-fixing bacteria in an acid forest soil. Appl Environ Microbiol 68:3818-3829

Rotthauwe JH, Witzel KP, Liesack W (1997) The ammonia monooxygenase structural gene amo $A$ as a functional marker: molecular fine-scale analysis of natural ammonia-oxidizing populations. Appl Environ Microbiol 63: 4704-4712

RStudio Team (2016) RStudio: integrated development for R. RStudio, PBC, Boston, MA. www.rstudio.com

Russ L, Speth D, Jetten MSM, Op den Camp HJM, Kartal B (2014) Interactions between anaerobic ammonium and sulfur-oxidizing bacteria in a laboratory scale model system. Environ Microbiol 16:3487-3498

Rysgaard S, Christensen P, Nielsen LP (1995) Seasonal variation in nitrification and denitrification in estuarine sediment colonized by benthic microalgae and bioturbating infauna. Mar Ecol Prog Ser 126:111-121

Seitzinger S, Harrison JA, Böhlke JK, Bouwman AF and others (2006) Denitrification across landscapes and waterscapes: a synthesis. Ecol Appl 16:2064-2090

Silverman JD, Washburne AD, Mukherjee S, David LA (2017) A phylogenetic transform enhances analysis of compositional microbiota data. eLife 6:e21887

Sintes E, De Corte D, Haberleitner E, Herndl GJ (2016) Geographic distribution of archaeal ammonia oxidizing ecotypes in the Atlantic Ocean. Front Microbiol 7:77

Skjemstad JO, Baldock JA (2007) Total and organic carbon. In: Carter MR, Gregorich EG (eds) Soil sampling and methods of analysis, $2^{\text {nd }}$ edn. CRC Press, Taylor \& Francis Group, Boca Raton, FL, p 225-237

Spring S, Scheuner C, Göker M, Klenk HP (2015) A taxonomic framework for emerging groups of ecologically important marine gammaproteobacteria based on the reconstruction of evolutionary relationships using genome-scale data. Front Microbiol 6:281

Sun MY, Dafforn KA, Johnston EL, Brown MV (2013) Core sediment bacteria drive community response to anthropogenic contamination over multiple environmental gradients. Environ Microbiol 15:2517-2531

* Szewzyk R, Pfennig N (1987) Complete oxidation of catechol by the strictly anaerobic sulfate-reducing Desulfobacterium catecholicum sp. nov. Arch Microbiol 147:163-168

*Tan E, Zou W, Zheng Z, Yan X and others (2020) Warming stimulates sediment denitrification at the expense of anaerobic ammonium oxidation. Nat Clim Change 10: 349-355

Teeling H, Fuchs BM, Becher D, Klockow C and others (2012) Substrate-controlled succession of marine bacterioplankton populations induced by a phytoplankton bloom. Science 336:608-611

*Volkman JK, O'Leary T, Leeming R, Nichols PD, Volkman JK (1999) Assessment of the sources, transport and fate of sewage-derived organic matter in Port Phillip Bay, Australia, using the signature lipid coprostanol. Mar Freshw Res 50:547-556

*Wang K, Ye X, Chen H, Zhao Q and others (2015) Bacterial biogeography in the coastal waters of northern Zhejiang, East China Sea is highly controlled by spatially structured environmental gradients. Environ Microbiol 17: 3898-3913

*Wang K, Zou L, Lu X, Mou X (2018) Organic carbon source and salinity shape sediment bacterial composition in two China marginal seas and their major tributaries. Sci Total Environ 633:1510-1517

*Watanabe M, Higashioka Y, Kojima H, Fukui M (2017) Desulfosarcina widdelii sp. nov. and Desulfosarcina alkanivorans sp. nov., hydrocarbon-degrading sulfatereducing bacteria isolated from marine sediment and emended description of the genus Desulfosarcina. Int J Syst Evol Microbiol 67:2994-2997

*Wiese J, Imhoff JF, Horn H, Borchert E and others (2020) Genome analysis of the marine bacterium Kiloniella laminariae and first insights into comparative genomics with related Kiloniella species. Arch Microbiol 202:815-824

*Wright ES (2016) Using DECIPHER v2.0 to analyze big biological sequence data in R. R J 8:352-359

*Wuchter C, Abbas B, Coolen MJL, Herfort L and others (2006) Archaeal nitrification in the ocean. Proc Natl Acad Sci USA 103:12317-12322

Kazdani Foshtomi M, Braeckman U, Derycke S, Sapp M and others (2015) The link between microbial diversity and nitrogen cycling in marine sediments is modulated by macrofaunal bioturbation. PLOS ONE 10:e0130116

Submitted: April 6, 2020; Accepted: November 9, 2020

Proofs received from author(s): January 19, 2021
Editorial responsibility: Klaus Jürgens, Rostock, Germany 